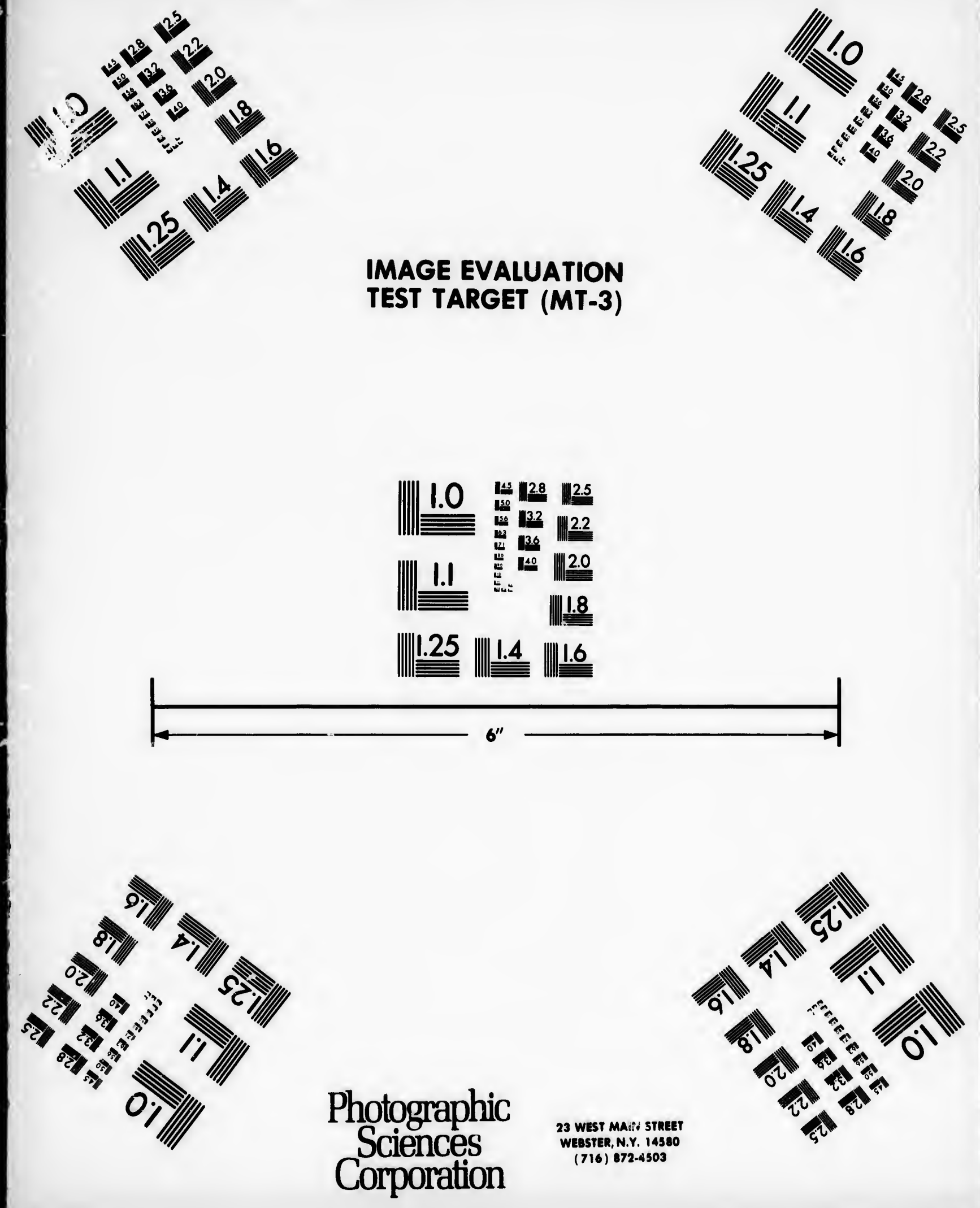




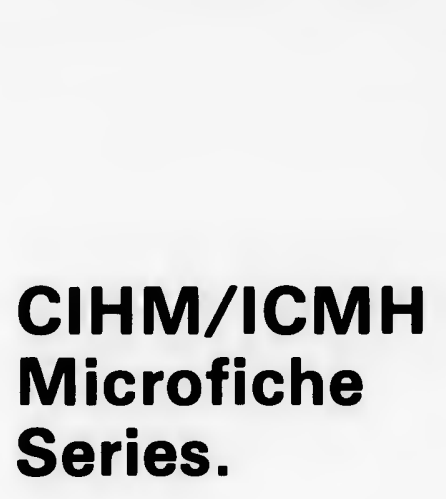

\section{CIHM/ICMH Collection de microfiches.}


The Institute has attempted to obtain the best original copy available for filming. Feetures of this copy which moy be bibliogrephically unique. which mov alter any of the images in the reproduction, or which may significantly change the usual method of filming, are checked below.

\section{Coloured covers/}

Couverture de couleur

Covers damaged/

Couverture endommagde

Covers restored and/or laminated/

Couverture restaurbe et/ou pelliculde

Cover title missing/

Le titre de couverture manque

Coloured maps/

Cartes ghographiques on coulour

Coloured ink (i.e. other than blue or bleck)/

Encre de couleur (i.e. autre que bleue ou noire)

Coloured plates and/or illuatrationa/

Planches ot/ou illustrationa en coulour

Bound with other moterial/

Relid avee d'autres documents

Tight binding may ceuse shadows or distortion along interior margin/

La reliure sorrée peut causer de l'ombre ou de la distorsion lo long do la marge intbrieure

Blank leaves added during restoration may appear within the text. Whenever possible, these hove been omitted from filming/

II se peut que certalnes pages blanches ajoutdes lors d'une restauration apparaisaent dans lo texte. mais, lorsque cela dtait posalble, ces pages n'ont pae ette filmbes.

Additional comments:/

Commentaires supplémentaires:
L'Institut a microfilmó le meilleur exemplaire qu'll lui e dté posaible de an procurer. Les détails de cet exemplaire qui sont peut-etre uniques du point de vue bibliographique, qui peuvent modifier une image reproduite, ou qui peuvent exiger une modification dans la mothode normale de filmage sont indiquds ci-dessous.

Coloured pages/

Pages de couleur

Pages damaged/

Pages endummagdes

Pages reatored and/or laminated/

Pages reataurbes ot/ou pelliculbes

Pages discoloured, stained or foxed/

Pages decolordes, tachotdes ou piqudes

Pages detached/

Pages ditachíes

Showthrough/

Transparence

Quality of print varies/

Quallté indgale de l'impreasion

Includes supplementary material/

Comprend du motóriel supplémentaire

Only edition available/

Seule edition disponible

Pages wholly or pertially obscured by errata slips, tissues, etc.. have been refilmed to ensure the best possible image/

Les peges totalement ou partiellement obscurcies per un feuillet d'errate, une pelure. etc., ont eté filmdes d nouveau de façon à obtenir le meilleure image possible.

\section{of}


The copy filmed here hes been reproduced thenks to the generosity of:

Memorial Univarsity of St. John's

The imeges appearing here ere the bext qualty posalble considering the condition and legibiltity of the original copy and in keeping with the filming contract specificasions.

Original copice in printed paper covere are filmod berinning with the fromt cover and ending on the lest pege with a printed or lllustrated impression, or the beck cover when eppropriate. All other original coples are filssed beginning on the first page with a printed or lllustrated impresslon, and ending on the last page with a printed or lllustrated impression.

The lest recorded frome on esch mierofiche shall contain the symbol $\longrightarrow$ (maaning "CONTINUED"), or the symbol $\nabla$ (meaning "END"). whichever applices.

Maps, plates, chara, ote., may be filmed at different reduction ratios. These too large to be entirely included in one exposure are filmed beginning in the uppor lett hand comer. litt to right and top to bottom, es mamy framee 20 required. The following diegrams lllustrete the mothod:
L'exemplaire filmb fut reproduit grdes d is sendroutes do:

\section{Memorial University of St. John's}

Les Images suiventes ont hed roproduites avec le plue grand soin, compte tenu de la condition ot de la netrete de l'axemplaire filmb. ot en conformite avec les conditions du contrat de filmage.

Les exempdaisew originaux dont la couverture on paples cet imprimt sont filme en commencant par lo premier plat et en torminant solt par la dernitre page qui comporte une emprajisto d'imprescion ou d'illustration, soit par le secend olat, selon lo ces. Tous les sutres exemplaires origineux sont filmde en commencant par la premidre pege qui comporte une emprointe d'impreacion ou d"illustration of en terminant por b dernitre page quil comporte une toile emprointe.

Un des symboles suivents apparaitre sur la demitre imege de chaque microfiche. selon le eso: 10 symbol — sionifie "A SUIVAE". Io oymbole $\nabla$ signifie "FIN".

Les cartes, planches, ablaux, ete., pouvent atre filmes des teux de riduetion difficrents. Loreque is documomt eet trop grend pour stre reproduit en un seul clichb. il eat filmb d portir de i'engle supdrieur geuche, do gauche ditroite. et do haut en bes. en prenant lo nombre d'lmeges ndesaaire. Lee dlagrammes suivanta illustrent la mbthode.

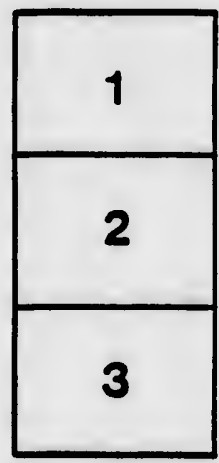

\begin{tabular}{|l|l|l|}
\hline 1 & 2 & 3 \\
\hline 4 & 5 & 6 \\
\hline
\end{tabular}




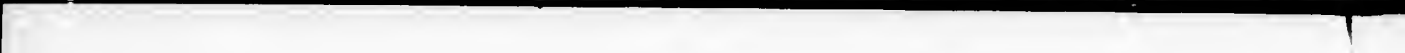

$\therefore$ 


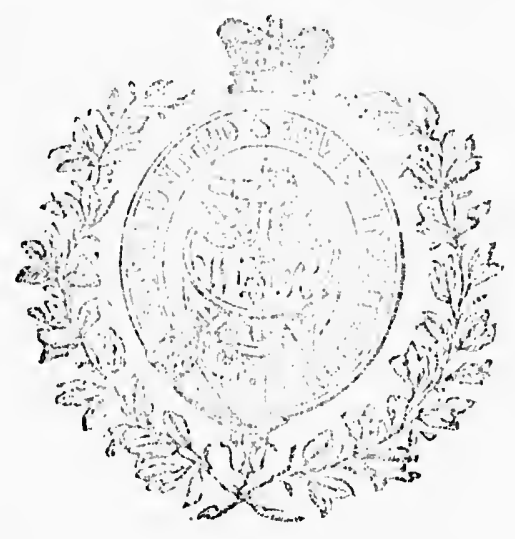

1111:

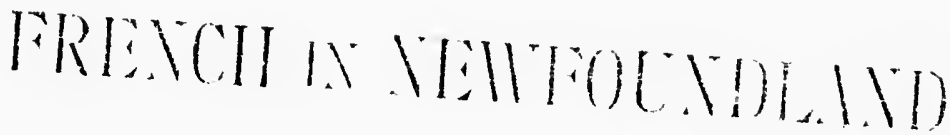

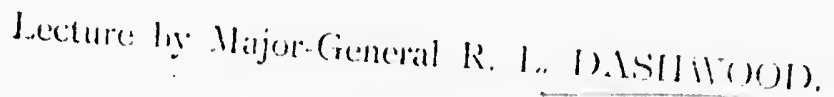

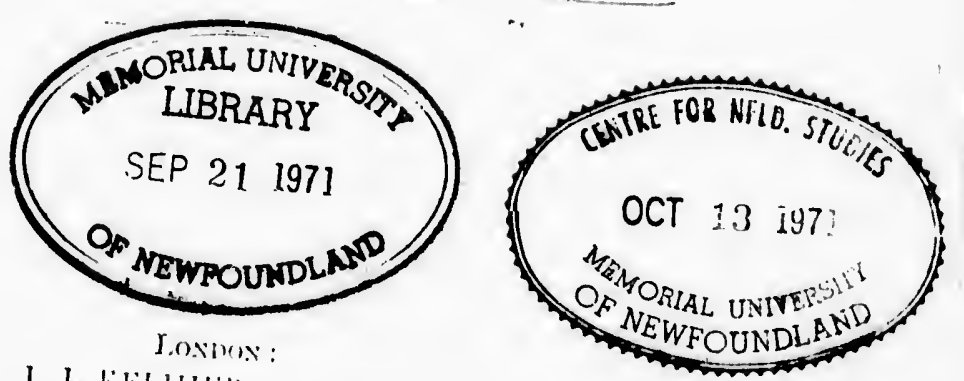

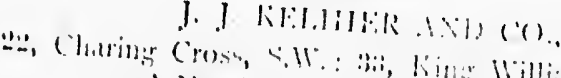

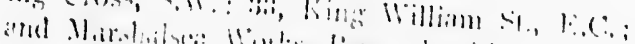


$\therefore$

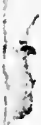

..t.

$+$

6 


\title{
THE FRENCII IN NEWFOUNIDIAND.
}

\author{
By Major-Ginaral R. L. D.ISHIIO()D.
}

Weducsdity, February 15th, 1899.

Vice-Admiral Sir Wuthali K. Kexwem, li.C.B., in the Chair

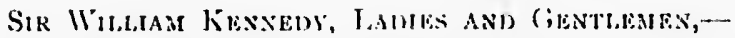

I HAVte, as the Chairman has informed you, had great facilities for becoming atcquanted with the question now before us, ats I hate spent many simmers and autumus in the Island of Xewfoundlant in the: last 30 years, and know woll the coast line and alse the interior. -

My object in giving this lecture is in the interests of the people af the colony, more esprecially of the proor fishermen, to show how they have becen treited by the British Government for the last 100 years and more.

The italics in the printed fart of the lecture are my own, the quotations from denpatchus, oprinions of the law oficens, etce, arr from oflicial sourecs, and will matinly be found in a forcign (litice . Memurandum, dated Malreh, lisio, and July, 1873 .

- Jrist to 1723 the French had made certain lodgenents in the island, especially at Placenti:n, which they hat fortified, and on oneoccasion they marched a force from that place to St. Johu's, which city they ciptured. but shortly after were driven ont and defeated hy a lsritish expedition.

13y Aiticle NIJl. of the 'Treaty of Vtrecht, 1713, it was agreed that "The islame colled dewfoundland, with the adjacent islonds, shall from this time forward belong of right achetly to Cireat Britian, and to that cond

liereignt Onice mens. 186iti. the cown and fortress of Illacentia, and whitever other places in the snid island are in the possession of the French, shall be yielded and given tip.

"Nor shall the most Christian ling, his heirs antl successors, or

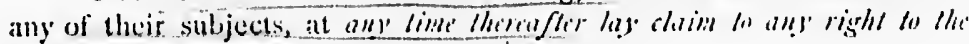

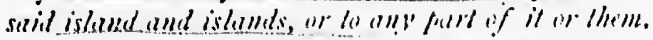

"Moreover it shatl not be lawfill fo: the subjedts of liance to forlify any place in the said island of sewfomellamel, or to crect any

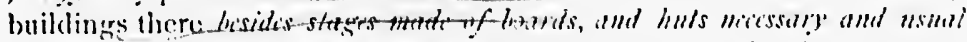
for desins of fixh, or to resort to the said inland beyond the time messmy for frishing ame drying a/ fish. But it shall be allowed of the subjects of liatuce in catteh fish and to dry lhem on land in that part only and in no other," which the treaty goes on to describe is hetween Calpe Bonavistal 
Foreig

Orfice

Istit. 
and Point Ricite, going romel by the nuth of the island. The French at this time produced a male wherein loint Riche was put at Cape Raly;

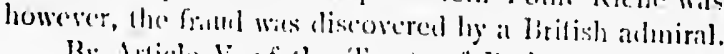

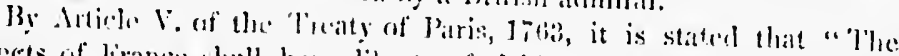

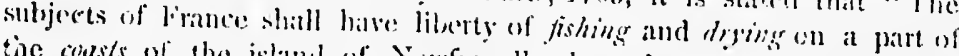

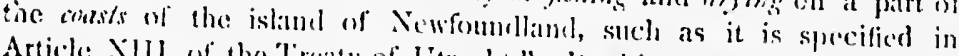

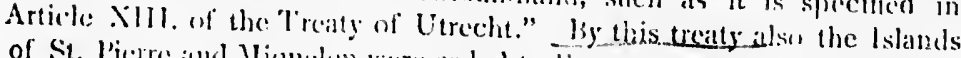

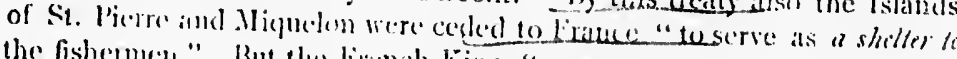
the fishemen." But the linench king "engigges not to fortily the sivid islands, fo enect no buldings upen them but for the convenience of the fishery; and to kees mpon them a guard of io men only for the police."

By the: 'Treaty of Vorsulltereres, the right of the British to New-

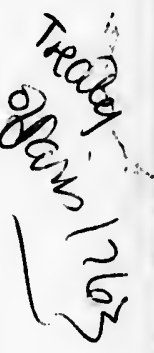

Foreign OMice me'mo. Isitis.

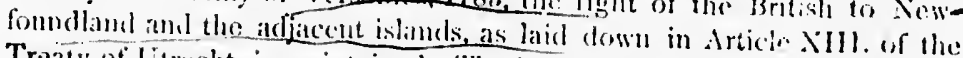
Treaty of Corecht, is maweined. The islandis of St. Pierre and Miquelon

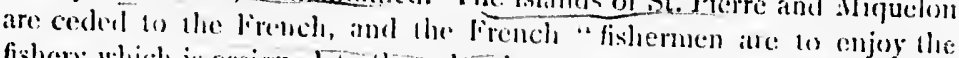
fishery which is assigned to lliem-by the present article, as they hat the right te enjoy that which was asigned to them by the 'Ireaty of Utrech,," and by this treaty, "in order to prevent the quarrels" which hat arisen between the lireneh and linglish hetween cape Bonavista and Came St. John, in conseguence of the mumcrots lititish settlers on that part of the coitst, the French gatse wh the right to tish between those proints, and in lieu thereof the treaty shore was prolonget from Point Riche to Canes Raly.

And by a Declaration of his Dritamnic Majesty, dalded September 3rd, 1783, it wils declared:--

"Po this rold and in order that the fishermen of the two nations may

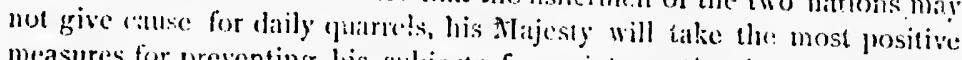

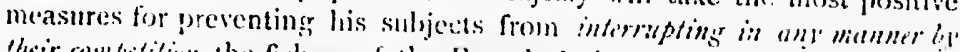

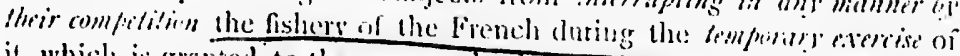
it, which is gramied to llicm llyon the codsts of the island of Newfonnd. land; and he will for this fiewpense caluse the feved sefllements which shall be formed there to be romored and his firintuc Miljesty will give

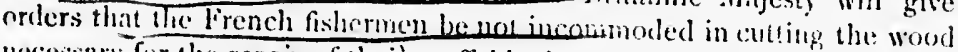
necessary for the repair of their scafolds dwes, and fishing-vessels.

"The Article XIII, of the: Treaty of Uiceht, ant the method of

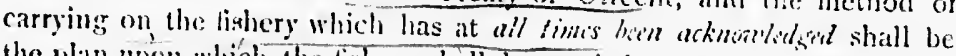
the plan upon which the fichery shall he carricel on there, it slall not be

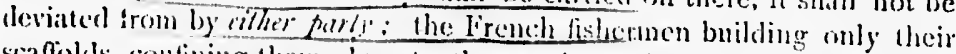
scaftolds, confining themselves to the repair of their fishing-iessels, and not wintering there; the sulpjects of his Britamic Majesty on their part not molesting in any manner the french fislomen during their tishing, nor injuring their scaffolds cluring their absence.

"The ling of Greal Joitain in ceding the Isiandes of st. Pinrre and

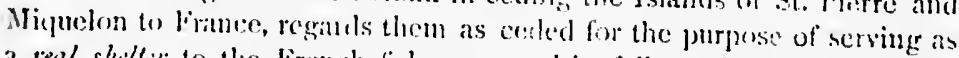
a real sholler to the French fishermen and in full confidence that these possessions will not become an wher of jablows hetwen the two wations." A counter 1)celitation was made by the Ifrench King on the: same day. liat as pointerl out by the law officers on $2.11 \mathrm{~h}$ March, i859, it was signed 

alter the British Declaration, with which the King of France declared "he is fully satisfiecl."

By the 'Treaty of liaris, 1811, the lirench right of fishing " "p, on th: ai Joreign (inli of st. latwence, was replated upon the sime footing in which it 1 stiti. stood in 1702.

This enactment was maintained by the 'Iriaty' of Paris of 1815.

following claims :--

1. An exclusive right of fishery on the treaty shore.

2. That all lixed British settlements of whatever nature on that portion of the coast are contrary to the treaty, and tiat the Firench have the right to demand their removal.

3. The right to catch fish of all descriptions.

4. The right to take salmon and other fish in the rivers, both in the fresh and salt water.

5. The exelusive right to the shore for hall at mile from the: sea.

6. The right to exercise jurisdiction on the treaty shore as regards what they may consider breaches of iheir treaty rights by the British fishermen.

7. The right to set up lobster factories on the treaty shore, and to grant concessions to their subjects to carry on that inclustry.

Now as regitrls the claim of atelusiveright to fish. It appears Ibict. "from the archives of the looreign Onice," that between 1718 at:d 17so, "that is to say from the Treaty of Ullecht to the brealking out of war in 1780, the rights enjowed by the fiench were 'concumen' only, and the attempts made from time to time by the latter to induce the Jritish Government to make their rights exclusive had been suecessfully resisted."

It also appears that Mr. Fitzherbert at the time of the making the 'Treaty of 1753 and the: Declaration, refused to concede the exclusive right of fishing demancled by lirance, but promised that the French should not be " molested."

Mr. litwherlert, in a further elespatch of May 4th, 1783, "stated that M. de Vergennes continued to urge the insertion of such words in the Declarition as would secure the carlusire right of fishery to the French.

"This attempt to obtain exclusive rights was, however, resisted," and "it will be deseryed that neither the Treaty of 1783 nor the Declaration annexed thereto confers any exclusive rights of fishery upon the French."

In adlition, the very wording of the Declaration which says " it shitl net he deviated from by eitly' purty" shows clearly that both nations were to fish. In litct, frior to the Declaration, the rights of the Finench were " not only concurrent but equal." After the Declarition, concurrent without interruption, which gave the french more or less a pre-emption. Governor Darling, in a despatch to Mr. Labouchese in 1856 , states that 


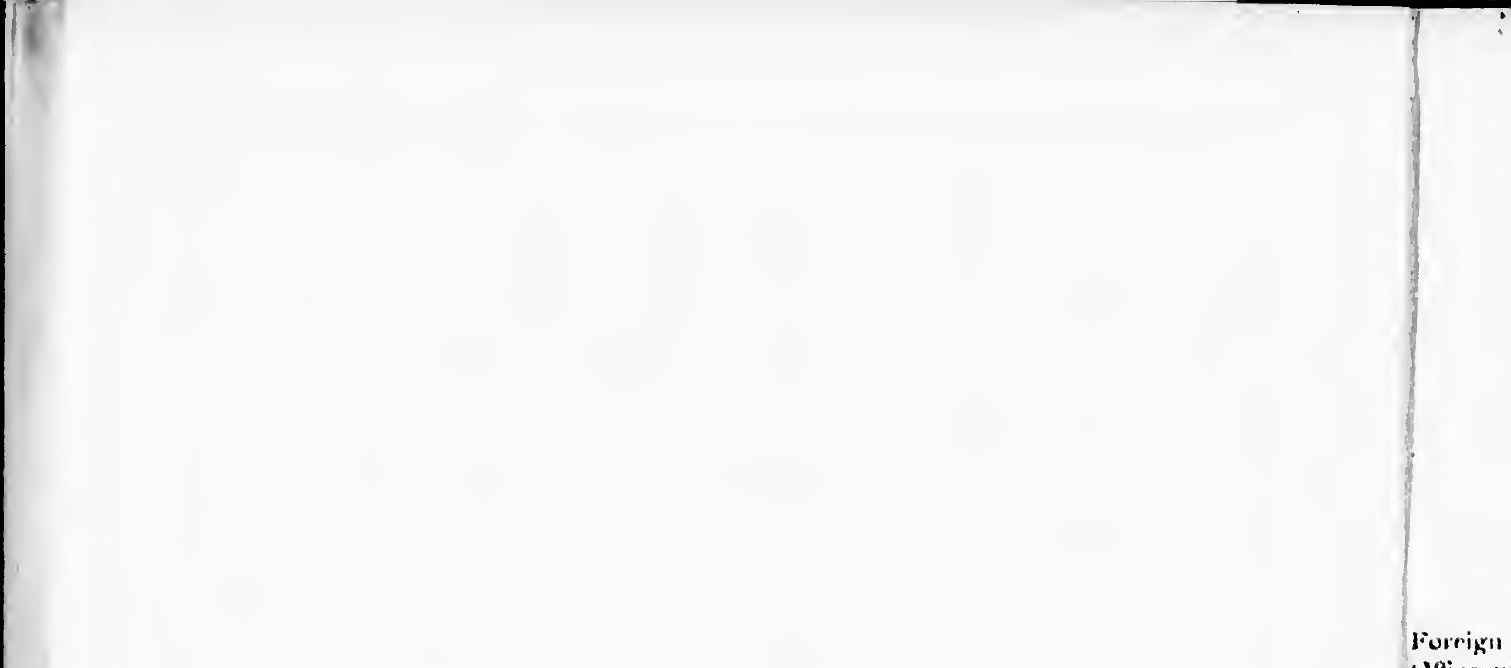

rorrign Istiti. 
several proclanntions of (iovernors hetween the years 1763 and 1783 speak of the French riglits as "riglits in common."

In 1818, the sane riwhts of fishing were given to the people of the United States, nor did the French inwatere with them. It wats remalied ly a British naval oflicer, Commander Knowles, in his report, that the French naval offerss interfered with the English, while they let the Americaus alone.

I.ord Ialmerston, in a despatcl, dated Forcign (omice, July loth, 1838, in reply to Cownt Scbastimi, who claimed, on the wording of the: Declaration, an exclusive right of fishing, among other things, sats :-

Foreigu

Shice memo. Isilit.
"The 'Treaty of Paris of 181.4 declares that the French riglat of fishery at Newfoundland is replaced upon the same footing upon which it stool in $\mathbf{1 7 9 2 .}$

"In order therefore to come to a right understanding of the question it will be necessary . . . to ascertiain what was the precise footing upon which the French fishery a tually stood in 1792.

"N.w it is evident that specific evidence would be necessary in order to show that the construction which the French fovenment now desire to pit upon the Declaration of 1783 , is the interpretetion which was given to that Declaration at the period when the Declatration was framed, and when the real intention of the patries must hatve lecen best known. It would be requisite for this purpose to prove that upon the conclesion of the 'Treaty of 1783 French subjects actually entered upon the cnjoyncnt of an exclusive right to catch fish in the waters off the colast in question . . . at the commencement of the war in 1792 ; but no evidence to such iffect. has yet been produced . . and moresver it does not alplear that such right was claimed by liance, or admitted by Fingland, at the termination of the war in 1801, or at the Peace of 181.."

And referring to the prohibitory proclamations of the linglish Governors after 1783, which were issued "from time to time on occasions when it was found that British subjects while fishing willin the limits in question, have caused interruption to the lirench fishery," Iord Palmerston says that " neither in the Act of larlianent of 1788 , passed for the express purpose of carrying the Treity of 1783 into cffect, nor in any subseçuent Act of l'arliament relating to the Newfoundland fishery, nor in any of the instructions issued by the $\Lambda$ dmiralty or Colonial Oftice, nor in any proclanation which has come under my vicw, issned by the Governor of Newfoundland, or by the British admiral upon the station, does it appear that the right of French subjects to an cxclusive fishery, either of cod-fish or fish generally, is specifically recognisce!."

And, in conclusion, he adds ". . . . exchsive rights are privilerges which, from the very nature of things are likely to he injurious to parties who are thereby debared from some exercise of industry in which they would otherwise engage, such right: are therefore certain to be at some time or other disputed, if there is any maintainable ground for contesting them; ard for these reasons when negotintors have intended to grant exelnsive rights, it has becn their invariable pactice to convey such rights in direct, unqualified and comproliensive terms, so as to prevent the 


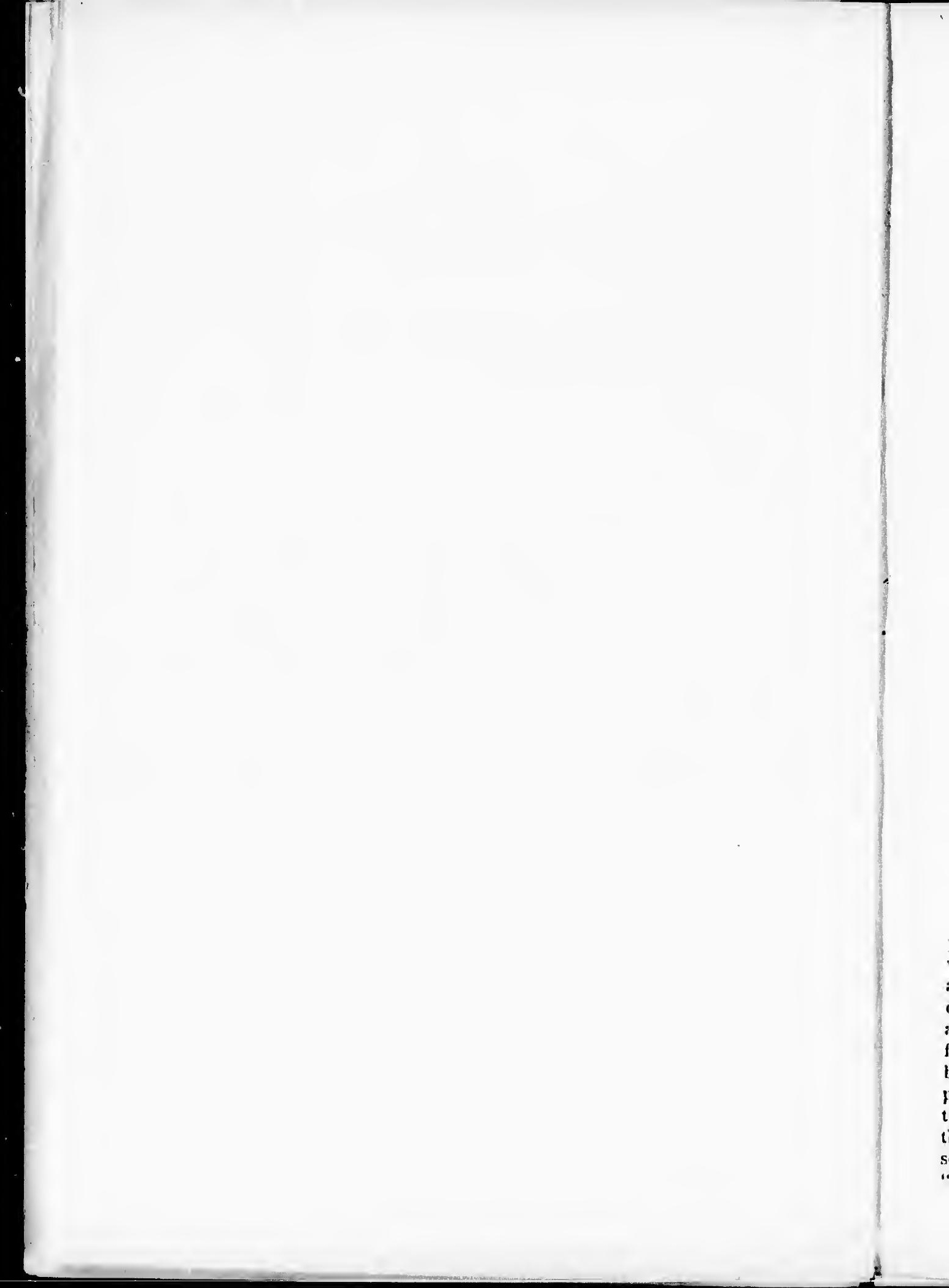


possibility of futurc dispute or doubt. In the present case, however, such forns of expression are entirily wanting and the claim put forward on the part of France is founded simply upon inference, and upon an assumed interpretation of words."

Such are the chief points in the eelebrated clespatch of I.ord Palmerston, one of the few British statesmen who have really safeguarded our Imperial interests.

The law officers of the Crown were consulted at different periods as to the exclusive right to fish. 'They gencrally laid down that British subjects might fish on the treaty shore, provided they could do so witlınt interrupting the French. Sir E. I.ytton, in his instructions to the Newfoundland lishery Commissioners in 1859, saicl, "The French right is therefore not that of an exclusiwe fishery, but that of a fishery free from disturbance by British competition." This is the claim made by the British Government up to the present time.

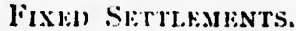

This hitherto has been the most dificult point of the treaties and Declarations, the lirench elaiming llat fixed settlements of any kind are contrary to the treaties, the linglish maintaining that the Declaration only referred to fixed fishing settlements, and that settements of any other kind are not eontrary to the Declaration. As a fact almost erery settlement on the treaty shore is more or less a fishing settlement.

Now, in order to get any clear idea of what wats really meant to be gramed to the lirench by the undertaking to remore "fixed settlements," and the caisses that led to such molertaking, it is necessary to refer to historical facts, which appear to lave been overlooked in dealing with this question sine the treaty of 1815 , by Secretaries of State and law oflicers of the Crown.

Up to the breaking ont of the war in 1783 the fishery was a ship fishery-that is to sily, was carried on almost entircly by fishermen from liance and linglind who came to Newfonndland for the season only, and then returned home. $L^{\top} p$ to that ditc pernanent settlement by the: British was not only discouraged, but contrary to the law of the colony. 'The fishery appears to have been considered a sort of freserve for certinin linglish adventurers. The master of the first British vessel to arrive in any bay in the spring became the "fishing admital," as lie was termed, for that bay for that season only. He had the right to choose any portion of the beach he filed on which to establish his "room," as it is called, that is, the area on which he ereeted his stiges and scaffolds for drying and curing fish (cod). These stages are practically a wharf built out over the water, the lower part used for splitting the fish preparatory to saltingr and drying; the heads and offal being thrown into the sei. Above are poles forming a kind of wooden gridiron, on which the fists are spread to dry. The fishing admiral had also jurisdiction to settle disputes, and other vesscls as they arrived chose places for their "rooms." It was first come first served. 
Foreign Onice me Istifi. 
THE FRWNCH IN NBWYOUNIAAN.

But the possession of a certain place one year did not carry possession for the next. On this heibl Chief Justice lieeves in 1793, before a committee of the Honsic of Commons, stated, "Ships' romms and all vacant and void spaces which may be turned into shipss" roms, by those who choose to occupy them are in common for the first taker, who may possess one for the seatson, at the end of which he must leive it . . . . for some other person the next se:tson." 'lhe albove rules existed also on the treaty shore, where the lirench fished in common, but the control of these fisheries was up to 1783 in the hands of the Jritish.

It appears that cren at this date British subjects had settled on the trenty shere, especially between Bonavista and Caje St. John, which wats the cause of the lirench limits being altered, the French comphaining that these sittlers on the plea of private ownership, and heing on the spot before the Firnch ship fishermen had arrived on the coast, obstructed the lirench in their fair choive of "rooms" on their arrisal. It was against steh unetgual conclitions that the French protested. For the Declaration says "ant fir this purpose," viz., to prevent interuption by the British. (This is clear ly the context.) "Itis Majesty will eause the fixed settlements that shall be found there to be removed." Therefore it mily be maintained that eren at that time, all fixed scttlements which did not actually interrupt the French fishery were not contrary to the Declatittion, non-interruption being the pith of thit document.

After the treaty of 1783 a number of the settlers on the treaty shore, who had gone there during the war, were removed without compensation, some to the inhospitable coast of Jahrator, where Newfindland history states many of them staried to death! What a disgraceful chapter in the: history of this country!

Foreign Oftice meno. INiti.

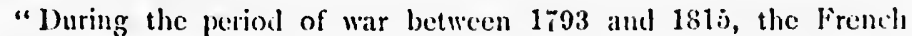
having been totaily excluted from the fishery, many British scttlers established themselves within the former leneh linits," and at the l'e.te of 1815 the old order of things un longer existed but had enirely changed. There were then no ship fishermes from lingland; the fishery was carried on on the part of the liritish entirely he setters. The Declaration grave to the French a pre-empition as to choice of fislingr places anel areas for elrying, ete. The reatsons for which the fixed settlements were to be removed, therefore, no longer existed. 'That part of' the Declaration was practically dead, and has never sinci: heen acted inl.

The lirench on heing granted their former riglits in 181 is did not insist njon the removal of these fixed settlements. but male use of their occupants to guard their hoats and other gear during their absener, which, contrary to the treaties, they lett behind. 'They also mate such so-called toleration on their part an excuse: for extending their fishesy to Iabratur and belleisle north, and thoy took possession of the salinion fisheries up the rivers, exported woot to St. Pierre and Miquelon, ant! erected permanent estahlishmerts, all of which acts were contrary to the treaties; but of which it appears for some years the British Govermuent took lit'l er no notice. 
'Plse Bricish popmlation on the treaty shore at the present date is over 13,000 , of whom over 99 per cent. ar' native-born.

\section{- Tue Ruint to (atcu Fish of any lini).}

Now, althongh the word "fish" applears in the treity, and not "cod," yet the wording of the treaty where it refers to stiges, etc., for the dryins of fish is incompatible with that of any other fishery but that of a cod fishery, as neither salmon nor lobsters are dried. In ablition, at the time of the "Treaty of Utrecht no other fishery was carricl on commercially, and the worl "fish" in Newfoundland has from time immemorial meant "coll" only. If a man wishes lo ask about salmon, herring, or any other kind of tish, he allucles to them by nams. Admiral Sir Hugh Palliser, gowernor of the colony in 1763 , stated the lirench fishery right included at col fishery on!', and grave no right to catch salmon. This view is also held by the colony, but the British forernment seen to take the view that fish of any kind are included, although ('omnt Sebastiani, in a communication to lord Palnerston in 1830, speaks of a cod fishery.

It has been afirmed that the word in the draft of the treaty of 1713 was "col," but that "fish" was substituted, as giving a greater purity of language. The original treaty was in latin: "Piscalurim exercere et pisces in terra exsiccare permissum crit "are the words used; literally to excrise a fishing, to carry on a fishery. There is no donht but what the fishery to be exercised was a cod fishery only, and this point should be vigorously maintained by our (iovermment. Some fo years ago there: was an action tried in the highest Courts of Newfoundland, which depended on the meaning of the word "fish," and it wis decided that "fish" in Newfoundland meant "cod" and nothing else.

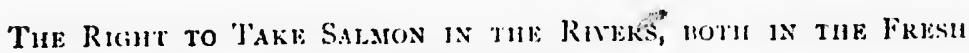
and Satt Water.

This right is denied by the IBritish Government. The fishery in the Foreign treaties is tlescribed as on "the coets/s," which is not wp the rivers. "Nhe law officers of the Crown concurred (1850) in the lisw taken by tord Oftice nentu. 1 sitic. Clarendon respecting fishing in the rivers especially for salmon, "that they are not within the scope of the Treaties and Declarations, and that the French have no right thereto, nor to fish in any of the rivers or moutlis of rivers in Newfoundland."

\section{The (Practicam.y) Exclusive Rigut to the SHoke for $\lambda$ Distaxcli of HaLk-A-MILE Fon THE Sin.}

'The French claim that the British have no right to occupy a yard of land or crect any building within the half-mile limit, oil the plea that such occupation may internupt their fishery ; also that the British are not at liberty to enquire into the bona foles of such alleged interruption, which "may be a mere contrivance to get rid of an inconvenient population": 


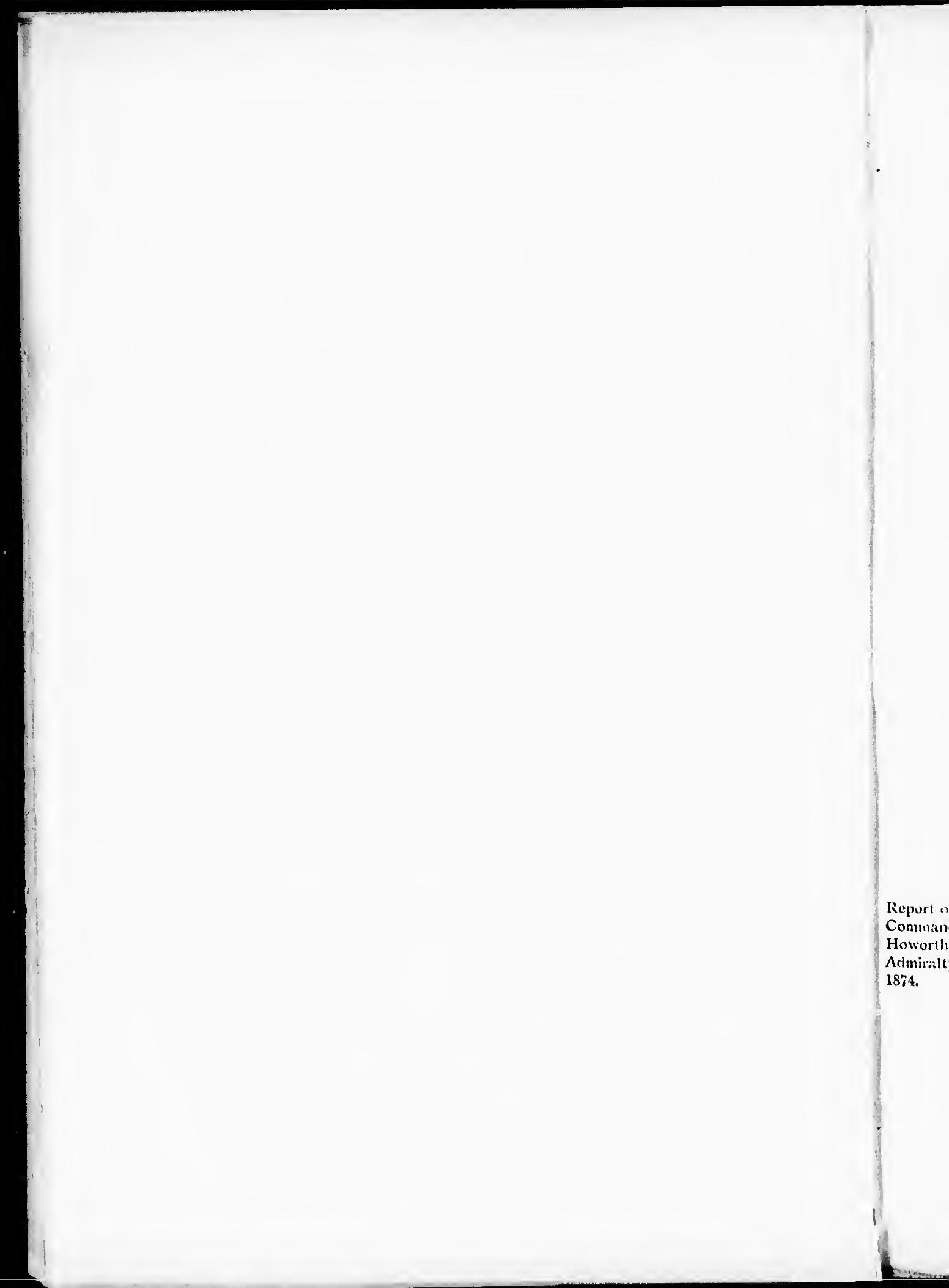


the French elaim that they are to be the sole arbiters is to what constitutes an iuterruption-to be judge and jury, in fact-is virtulal claim to territorial serereignty of the shore; a clicim which Mr. Waddiugton in 1886 actually made when he maintained that this right to the shore "was vested in them as part of their ancient sovereignty of the isiand which they had never relinquished." Such a chim is absolutely untenable, as it is dircetly at variance with the text of the Treaty of Vircht, which debar: the French from claiming " any right to the said island," etc.

"At most the French, by the treaty stipulations, have a right only to the shore which they can use," or bonat fill require to carry on their coll fishery. 'There is no mention in the Treaties or Declaration of the halfmile clisimed by them.

Now the area occupied by a "room" in which fish caught, in say 10 miles of sea, are cured, dried, etc., would not be more than about 300 yards long and 200 wicke. The "stages" arc erected close to and partially over the salt water. At the prescit time there are only about seven French rooms in the 800 miles of coast that forms the truaty shore, if measured by following the infentations thereof. 'The amount they really reciure is therefore infinitesimal, considering the length of the treaty' shore.

The most uncalled-for and groundless complaints of the French are includel in their determined opposition to the erection of wharfs for the exportation of minerals and other produce, and especially to the opening of mines within treaty limits. The British (iovernment has more or less given in to such complaints on the part of the French, though, proviled the opening of such mines or building of wharts does not in any way intermul the lirench fishery, it is hard to see the necessity. of giving way to complaints that are really frivolous and unfounded, and the almission of which involves great hirdslip) on the colous, and directly prevents its development.

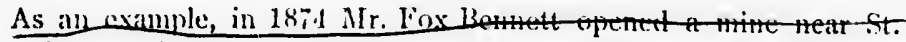

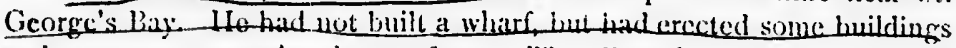
and sot some to the surface. 'I'le French strongly objected.

Repurt of

Conmando Howorlli lo Adinirally, 1874. Commander lloworth, R.A., in his report states " That as thu'st huildings were 12 miles from the nearest French fishing station, lat could not conceive that the fireuch can ever be injured by the prosecution of these most important works." But under pressure from the British Government Mr. Bennett closed down his mine. 'Iwo years atro another mine was opened at l'oint Blufi, 20 miles from any French fishing station, to which the French also objected, especially to a wharf therc. And the J3ritish Government not many years ago actually forbade the building of a railway that was: projected, hecause its termimus was to be on the treaty shore at St. (icorge's Bay, and that French treaty rights might possibly be "affected," although no Frenchman had been near the spot selected. for many years. At the present time there is a railway station at St. Cicorge's Bay. Other whats's lad been removed at various timies by orders of the liritish authorities. Some have not been interfered with. 


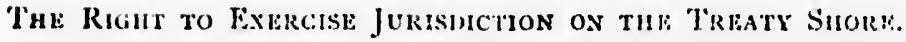

It is an axiom of intermational law that the sovereign power alone can excreise at hority withiu its own limits. By the 'Ireaty of Utrecht Great Britain was confirmed in the cxclusive sovereignty of the entire island and adjacent islands; the French, therefore, camot have juriscliction on the treaty short. In 1853 the Queen's Adrocate laid down " That by the Jreaty stipulations the French ajjoy no right of jurisdiction within their lishery limits." Mr. Addington, in a despatch to the Admiralty in the same year, stated that "We altogether leny the rigint of the French to take the law into their own hands and to drive away Finglish fishing-boats from the Treaty limits." In 1852 a British warship was stationed ofl the coast of Newfouadland wo protect the british fishermen, because the lirench had taken the law into their own hands. Lords Clarendon, Cowley, Rosebery, and otlier Ministers have protested against such action on the part of the French; but it still continues! Though since our surrender on the lobster question, the firench men-of-war have more or less ceased their argressive acts, which prior to that date were very frequent. Some light is thrown on this by the instructions of Sir E. Lytton, who was at the Colonial Onice in 1859, to the Newfounelland Fishery Commissioners, in which, whilst he fully admitted that the French had no right to take the law into their own hands, yet he goes on to say": " But Her Minjesty"s Government have to instruct you not to entertain Ibid. any objection to such proceedings on the part of the French, etc." That is to say, our (jovernment, whilst protesting on paper against such actions by the French as contrary to treaty, and pretending to protect the Newfondland fishermen from such depredations, give secret instructions to their agents to shut their eyes! Many people wonld consider this hardly straightlorward and not a very creditable proceeding, but I dare say it may be quite in accordance with the traditions of the loreign Office. It was not until 1862 that three-Britivilmen-of-warwcre. every fishing scason, stitioned of the treaty shore of Newfoundland to control the fisheries. Such a task cannot be a very pleasint one, for it will probably be admitted that both sailors and soldiers are above all things lovers of justice and fair play; that beingr so, navil officers on the treaty shore would, no doubt, sometimes have a repugnance to carry ont their instructions from Iowning Street, when such orders, whi :h they are bound to obey, press liacrily and even unfairly on the fishermen of the colony; which sometimes they do, especially as the complitints made by the French men-of-war to ours as to alleged actions by the natives contrary to the treaty, to which our officers are obliged to pay attention, are frequently eventually found to be groundless and frivolous. In fict, if it was not for the tact displiyed by our naval officers there would have been a serious disturbance on the coast long agro.

The Right to Skt up Lonstek Fac'ories on the Treaty Shoris anj) to Grant Concessions to thik Senjects to Cakry on THAT INDUSTKY.

The first Briiish lobster factory erected on the treaty shore of Newfoundland was in 1882 at St. 13arbc, another in 1883 at Port Sanders. Up to 1887 
there wats no protent agrinst or interference with these findories, thowgh

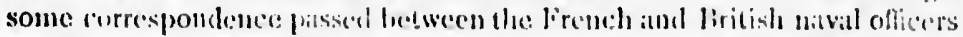

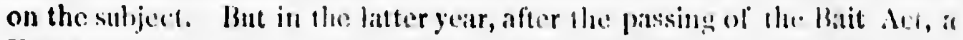
French man-of-war, withont notice or formal protest, de:stroysul a mumiles of lobster trips at the above-mentioned pheces. In Jume, Isst), at Fench war-ship destroyed traps at l'ort Sanders, and in fuly of that year, ion

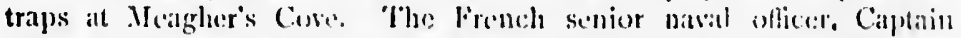
Humamn, alse complained to the senior British nawal whicer that thess: lobster tlipes interfored with their fishing operations, vi\%, the catching of capelin for bait. These complisints turned nut to be altugetleer frivolons, as ciapelin do not frequent the more or less rocky porlicus of the const where lobster traps are: set. Capelin come to the shore only on simbly beaches, whese lobster traps are not set. As a further proof that these: complaints were gromulless, there are nuw some forty English lobster factories on the treaty shore, and some ten lirench, and no complaints

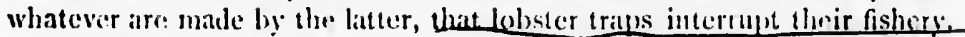

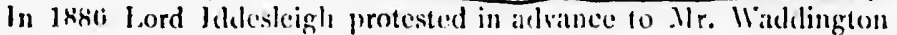
against the crection of lobster factories by the l'rench; he sidicl "that such a course is not allowed hy the truaties and must be disiontinued." It would have been well if our fiovernment had stood to these worls. Before 18 ss the French oljected to our fictories on the plea that such industry interfered with their fishery, hut in 1 sk8 they set up the conterytion that they had the right (lobsters heing fish within the meaning of the treaties) to take them and also (erect factories to pauk thatm. This they proceeded to carry out. In September, 1 s8s, the Forcign ( Iflier addressed a note to France calling attention to the illegality of liventh lobster packing, and a further protest was made by Lord Salishury citrly in 1 ss: "agatinst in assumption of territorial rights in derogattou of the sovereignty of the British Crown." Nevertheless, the lirench continued to erect lobstcr lactories. Lord Salisbury tlan suggested arbitration, but this very rightly was refused by the Colony; another attempt was mate to go to arbitration before a court, that also failed. Whe British (jovemment then wichont the consent, andigienst the wishes of the lejisliture, toncluded a uodus ariudi, which is in force $\Perp$ to the present ditt, by which ill factorics worling on the Ist July, 1880 , were to stand, both lirench and linglish, and no new omes were to he built by evither party, without mutual consent.

'The legrislature protested most strengly against the molus rizendi, which gave the French a lous standi in any luture negotiations to which they were not entitled, and the fact of its being male without their consent, they considered wats practically an intringennent of the promise made to them in $1857 \mathrm{ly} \mathrm{Mr}$. Labouchere, "that the consent of the community of Newfoundland is regarded by Ller Mitjesty's (jovernment as the essential preliminary to any modification of their territorial or maritime rights," nor was even the Government consulted ats to the final form of the modis zivendi.

It is perfectly clear that at the time of the 'Treaty of Utrecht no such industry ats lobster packing was ever contemplated or even dreant of: it 
$n=m$

) 
is still, if possible, more clear thit the lamguagre used to descrilu" "the fishery" in that treaty is utterly inapplicahle: to lobster eatchieg and

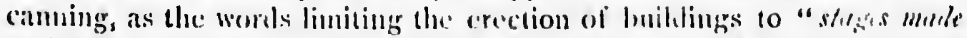

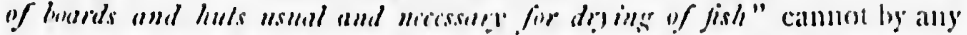
ingenuity be: made to cover a lobster fictory, whether roofed by amat, wool, or iron sluerting, with a boiler and furnate on at lirick foundation, timning appatratus and all the rest of it. As regands the lobster industry being an interruption of the lirench eod fishery, of course at lobster fartory on shore eamot alfect the capture of fish in the scia. Cod frequent deep water, lobster shallow water. Thurefore Iobster trips are not set in the places frequented by eod, meither is the cipture of herrings, capelin, or squids interfereal with hy lobster traps. l'rovided, therefore, that the factory does not occupy the gromol bimi fiet repuired ly the French for their " rooms" or Irying platces, it connot in any way intermpt them.

As to the Fromeh granting concessions to their subjects to luild factories on the treaty shore, which they did in Isss, it was an ambations move, and a gross infringrement of the treatics. Jhe French also try to make out that our lobster factories are illegal as coming muder the head of fixed settlements, sedentary cestahlishments, ats they call them, that is to say, establishments that are permament aud occupied all the your romncl. Now as the lolister seatson is only in the summer months, there is no necessity for our people to remain in these establishments heyond that period, in which ease they would not be fixed settlements, even allowing the linemeh claims on that head, which we lispute.

With such a strong cace, absolutely unassailable as fat als the factories are concensed, it is a pity that our (Fovrument, who on this question sliowed great weikness, especially Lord linutsford, who was at the Colonial Office, instead of grivingr waty, did not sily to france in effect: Your factories are absolutely contrary to the treaties, and must be removed. We shall support our subjects in the lobster industry, provided they do not in any way interrupt your fishing opcrations. This stand should be

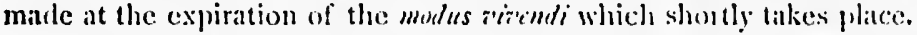

This modus zitudi, which has now lasted for eight years, bore cspecially laardly on those settlers who hat not erected a factory by 1st July, 1889, for while the more fortumate people obtained a monopoly, the ofluers, although they could catch lobsters, were prevented from packing them, and if they did so, their factories were destroyed; at the same time they saw the French with over a doz'll factories, quite contrary to treaty, carrying on a lucrative business on British territory, nom which they, British subjects, were precluded.

As at the peace of 1713 , when we first gave rights to France, and also in 1814 and 1815 , when we re-granted those privileges, we were the conquerors, surely we have a prior right over the French to interiet what it really was at that time we unete them a present of.

The priuled puper here ended, and thi licturir spoke as followes:- 
Now there hase lwon several athempts to make armigements with the

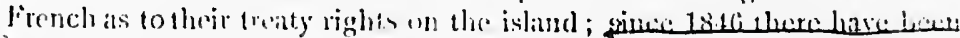

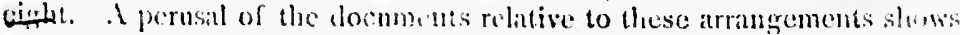
that what the british Govermment willted was to get rid of a very disigeredalue question all all hazarels, and it was quite a secondary consideration Whether Newfombll-mit cante of second best or not. All these arrangement: fell to the grommol becamse the colony very rightly protested very strengly against them, as they were very one-siled, and much in the incerests of France lither than $N$. w foundland. The last arrangement, which $f$ will explatin to you-as more or less a sanple of the remander -Was made in $188 \mathrm{i}$.

It was at the end of $188:$ that the British (jovernment and the: firencli (iovermment arranged to try and come to some agreement; four Commissioners were to meet in P'aris, two british and two lirusch. Sir IVilliam Kemedy, our Chairman, at that tine Cilptain Kennedy, had an itcat that he would be cmployed as one of the British Commissioners. () course, a better selection could not possibly have been made, lecause Ciptain liennosly had just come of the coist of the Newfoundland fisheries, alter there vears' service there; but the (iovernor of Xewfoumbland at that time, Sir John Glover, who was quite atwate of the ansicty of the Jiritish (jovermment to come to some settlement-in fact that they were mors or less riding for a fall -winamed the Colonial Office that Ciptinin kennedy knew too much! Therefore he was not sent, hut insteal, two gentlemen, one conneted with the forest. (Onice, and the other with the Colonial Office: Mr. Clare Ford, and Mr. Pennell. There was not very mueh fear of those grentlemen knowing ton much. hecmse rally they knew nothing at all, or very litte. I helicece Mr. Clare had been once to Helitis, which is 5.50 milis from Newfoumlland. Cine of them knew anything about the const line or the way the fislery wis carried on, and very polnably they wonth not have been ahe to tell you the lifference between at cod-tish and a capelin. The biench

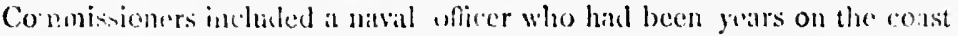
of Newfoundland. These gentlemen, Mr. liord and Mr. lemneli, west to laris, and at the cud of two fears they unde a final arrangement. I will explitin to yon its provisio s.s. I must first of all tell you what wers the so-called concessions given to (irobll liritain. Gireat britain wats to be allowed on the part of the may marked rod to have seltlements other than fishing setilements. 'The liritish Government have always contended we hald at right to hawe settements which were not fishing setllements anywhere on the shore of Newfoundland, and as a matler of fict practically almost all the tishing settlements on the treaty shore of Newfoumblland are fishingr settlenes.ts. 'Threre are at present some 13,000 people there. We hatd these setimunents everywhere, provided they dial not actually intermet the linench in their fishery operitions. Another thing is that the red mark on the map is what is known in the colony ats the straight sliore, than is to say, it is : shore of more on less perpendicular cliffs, whire you could not lard en in a canoc, devoid almost of harboms. 'The only' harbours given to us winth much were in St. George's Ba!g, the 
$\Gamma^{\prime} \%$

) 
Bay of Islands, and bonne bay, so that il was really no concession to us

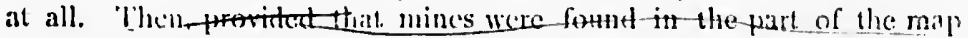

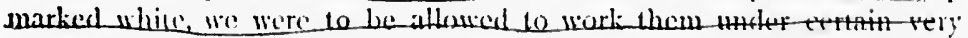
strimgent and hamporing compitions. A liritish naval oflicer and a lirench naval otherer might agree as to the site for the wharf (this grive the French a veto), amd hatring (lone so, it wharf might he bitilt on the shore, but all the paraplumalia commeted with the mines, that is, dwellingr-houses, shops, warthounes, cte., were to be plawed at a distance of 800 yards back -in some lew cases 500 yards-and were to be joined to the wharf by a railway fines in. Some temporary shelters were allowed to be put within 1.t yarls of this railway for the provisional storige of mincrals and tools. I do not hesitate to say that if the mines that are working and have heren working in Newfoundlind were hampered in that way, those restictions would have alded most enomously to their expense. To build a railway half a mile back on that precipitous rocliy coast woukl be very expensive inded. Not only that, but we have a righth, and the Britiol covernment maintain that we have the right, to have settlements on imy part of the treaty shore which are not fishing settlements, amb therefore provised we do not interfere with the french, which we are uot likely to do, we have a perfect riglit to have those tised settlements. So this so-called mining concession did not give us anything worth having. Is I have alrealy observed, we have a right to any kind of settlement it it does not intermut the liench fishery.

The'n the linench gave up their chaim to the exclusive right to fish. That clain they hat no right to, and we have always exercised a concurrent right up to this date. Therefore we got nothing out of that.

Now I will explain to you the rery solid concessious which ou that occasion were given to lirance. In the first place, these parts marked white on the malp contain every single harhour of any value on the 800 miles of treaty shore, with the exception of the three l hate mentioned. These latrbuss, in the parts left white, in fict, were to be practically ecserved axdusibely for the use of the lirench. It is quits true tiat in these harbents reserved, any british setters: living there: at that time might be allewed to remain, lat me new dwelling-houses were allowed to be built. That was a great concession to firance, and a great hlow to the Colong, beatuse hitherto lluere had bow nothing to present any settler building houses on any part of the slanre, provided he did met interrupt the lerelich. Moreover, it put an entire stoplere to any increise of the british pepulation on that part of the treaty shore.

Then the lirench said they abandoned the fishing in the rivers, but were to be allowed to fish as firr as the witter remaincel silt. Here they made a virtue of giving up what they had not the fatintent right in the world to. Then this clituse goes on to say, they (the Jirench) are not to be allowed to put fixed batriers in the rivers capalshe of impeding the fish or navigation. New. ats far as the water is salt is mp to the top of the tide, a considerable distance in some place:, a mile or a mile and a half. 'The Newfinmellander is only allowed to fish with a net in the tidial waters; not in the fresh waters. Ife is also restricted to a cerlain extent by 
bocal latws with regard to the length of his nets, the sia of the mesh, and the distemee of nets from each other. The lerench wonld hate beria entircly exempl from anything of that kind, and, proviled they lefi room, for a boat, they might build a fishing weir, and they might have ats many nets as they liked one hehind the other. In lain, that clanse hamded oser to the firench practically the entire control of areag salmon river on the treaty shore. The Newfommllanders would ton he able 16 put nets in front of the lirelleh, becaluse the firenth would he protected by the proviso of non-interilution. Putling a net in fron of another man's net would certainly be interruption; all they could du would be, if there was romm, to put their nets behind the french nets, and there? would not be much chince of getting a lish in such a place. A grood many of the settlers living on the estuaries and mouths of those rivers have alded to their livelibood considerably by catelhiner salmon; they might do a food deal more only the rivers are unfortunately considerably poached, and the cod traps outside are making great batos with the salmon. These men have a sort of prescriptive right to errtain salmon posts, as they are called. It rery often hats passed liom fither to son for generations. Il this salmon clause had been passed, all the rights these

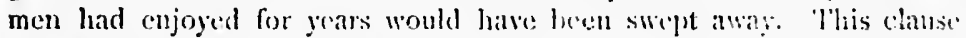
was a most abominable giving away of am important right caclusivel; he]d by the colony.

+ The next clause gave the French he right on purchase bit at any time in the parts of the shose which are nom-treaty. Thatl was a very important concession inclect. That I will explain presently Another clause allowed the French to import free of duty anghinge they litiol. They were to pay wo light dues or purt ciucs. If the firench were allowed, in the harbours where they have exchesive pussession, to band whaceo and rum and all that sort of thing, it would circulate in the comtry, and erery French harbour would le a hoobed of smenselers.

Then there was anothur clauses which allowed to the lireneh

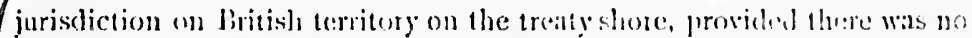

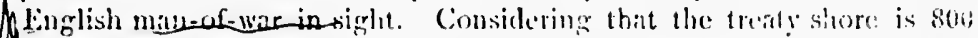
miles long, and that there art only three liritish men-of-nat there, it is tot 1 very often they would he found torether, and the firench grencrally cruiss

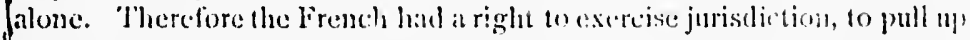
fond remove the nets and fishing grear of lirisish settlers on the pleal that they were interfering with firench tishermen. They coulal also, if clamige" was done, either at sea or on shore, hold al count and atsesss the damage, and the report of that comt was to be recrived as evidente in a liritish

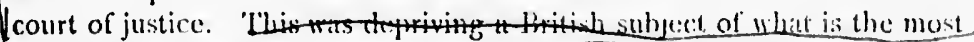

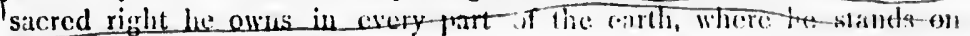

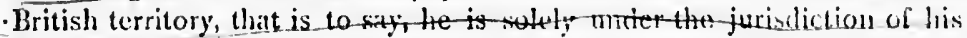
own people. It is a right every lirenchman has. We cannot try at Frenchman in lirance; why should a lirenchmatn be allowed to try an Fuglishman in Newfoundlind? I think this was a most abject and monstrous surrender on the part of (ircat dititian. Is it likely that Newfoundland fishermen would gret even-handed justice from litench navil officers? 
Net, 
J3y another clatuse the French were to be allowerl to have two families per lambur-in linge harbours 1 wo, and in small harbours one. This must be fonked npon rather at the thin end of the wedge of colonisation, and in the 'leaty of Uerecht it was very carefuliy provided against. "The word "family" is rather an indefinite term. "Family" mily mein a man and his wife and children, or all his relations. To julgre trom aur previons knowledge of the firench -who are very clever in these matters, alli are very really, if you give them an inch, to take an ell they would no doubt have put the more liberal interpretation on the word "limily." I believe at the present moment the population of France is nearly stationars, but the elimate of North Ancrica has, apparently, a feroliar effect on the firench people who lise in that part of the world, ats it renders then extremely prolifie- - a baker's clozen is at common number in a linelle family in () mabec. I do not know that there is any reason to sunpuse but what the climate of Newfoundland would have a similat effect. Fou can judge for yourselses the number of people there woukl hate been in those hirlours in the course of tweniy years, not to say thirty or forty, if they hat been allowed to halve nue or two families there. These fanilies must have had permanent habitations, and when they were not fishing in the winter, they would be competing with our scttl.ro in eattehing furs (which are wery viluable, especially that of the fox), shorting leer, and so on, althengh by the treaty the firench hat not the right to shoot enen a musk-rat. In the course of forty years that part of the coast would hatse been to all intents and purposes a French cololiy.

Now, I hope: I have make clear how Ineless were the rights conceded to (ireat. Britain and how exeedingly alvintageous were those given to limence, ancl, moreover, how very important privileges, cxelusively owned by the (olony, were lamed over in part or wholly to lhe liench, without our rectising in ('schituge anything approatching to an equivalent. The Colony was, in fint, entirely griven an:ay.

Wedl, this previons derment wats signed and agreed to by both fioveruments. The French were very cock-it-hoop, and were prepared in do all sorts of things on the licity shore, to pivis concessions

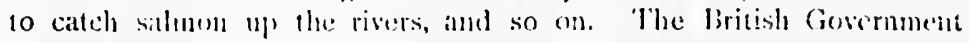
thought that at has they hat get theit wicked wity, hecillse they had

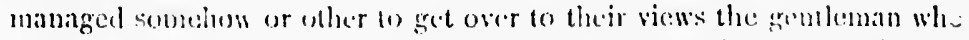
at that time wats l'remier of Newfoundland. Ile was a latwere and hat no personal interest in the fislaes ins. He played into the hands of the British and French fiovermments. He halplened to have been made a knight two or thren geats hetores and possibly if the thing came of he might

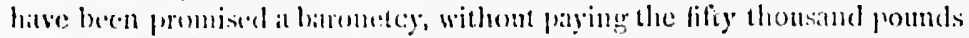
which we were told the other dity was the price of thiat hemour. However; he was urged to all the legistature of Newfoundland together ats soon as possible to ratify the treaty, als all it requireal wats ratification ly the Colony. Jowever, there is matry a slip. 'The British (iovement were; not ret out of the wool. liortunately, helore the legislature of Newfounilind exmlil meet there: was at general election, sucl the people in 


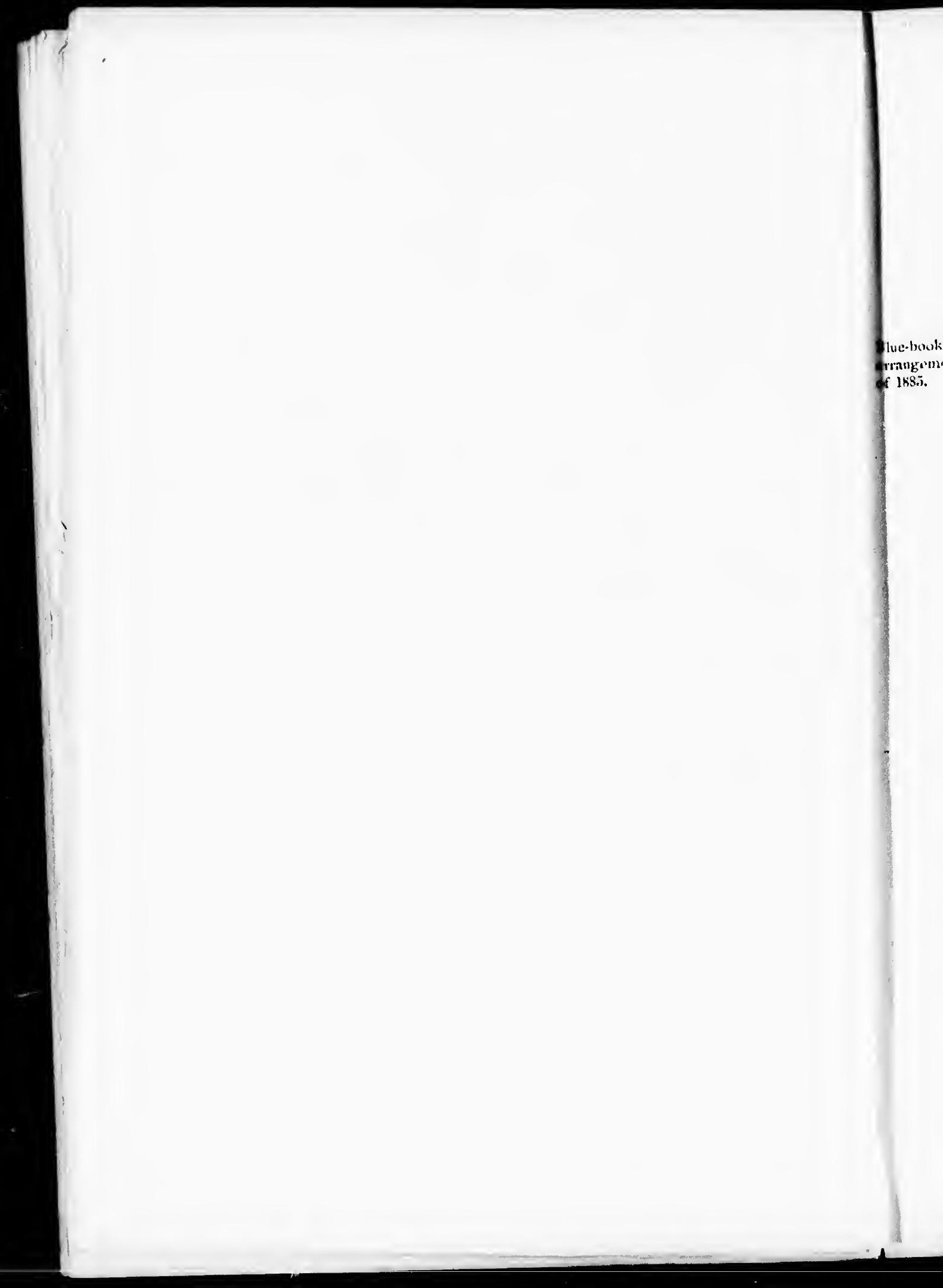


power were thrown ont on this very arrangement, and the party who canc in declined to ratify it. The leoreign Oflice was very angry, and tried to bully and compel the new Gowernment to agree to the arringement an the plea that they were bound by the promise of their predecessors. But the Covernment of the Colony declared they were homel by nothing of the kind, and they flatly refused to ratify it. 'The liori-lenuncll arrarigement of 1885 wats therefore dead, hut the colony had an exceedingly natrow escape.

The premise of $185 \%$ was respected, althongh I.ord fohn liussell, in 158.5.

a despateh dated 1860, proposed to ignore it, and make an agreement in defiance of the wishes of the Colony. Lord Derby descrilied this arrangement as "most ailvalnagreons to the Colony." (islonel Stanley followed suit. I.ord Salishury' said he "entirely" concurred" with it, and he? wrote a despatch in which he highly complimented Mr. Find and Mr. Pennell on their labours, and for their services on that oceasion Mr. Ford hecame Sir Clare Ford and was not long afterwards promoted; and Mr. Pennell was made a C.B. I think this shows prelly clearly that failure and lefeat in the diplomatic service are not a bar to promotion and honours.... on the contrary, it is likely to leal to then. IIe once shot an admiral for errors of julyment, to chenurage the other:-as Voltaire said. I do not me:an to sugrgest that a diplomatist who alsiolutely fails in the mission he is sent to perlorm, and who gives anay his colntry, should be hung or sliot, but surely he shoula not be a gainer therehy.

Now, in 18861 happened to go out to Newfoundland, and on my arrival 1 spolic to some of the leading people, and said I was very glad to sec they liad got rid of this inipuitous arrangement. I fitrher said, "Yon must not rest on your oars. It is a very important mitter that the public at home shoukl know all about it and how unfair it wats to the Colony. Some of you should write to the T'imtes or to a maratine and expose the whole thing. If you to not" (it was not donce. " vess may depend upum it that if ally difliculy crops up in future aldout the treaty shore guestion, the British Government will turn round on you and sity, "this is all your fault, breause you did not agree to thill evecllent arrangement of 1885." It is a tather risly thing to propluey in these days, whatever it might have been 3,000 years ago; but on thiv occasion iny proplecy became absolutely truc.

In two or three years the lobster question came 110 , aml lord Knutsford, in response to some memorial from the linvernment of the colony dealing with mines on the treally shore, annont other matters, threw it in their tereth that they had not ayreed to this arrangement. lord Salishury, about the same time sfualings in the louse of londs, was reported (o) have saich, in alluding to the : arrangement:- "It became my province to sign an arrangument initiated by my nolle friend opposite, lord Granville, in my upiinion a most equitable and workable; arrangenent, which the people of liewfoundland, apparently at a heated timc of election, threw out and thereby lost a folden oppertunity." A golden opportunity indeed! Where is the golden opportanity? Nowhere, but for the French, who were very 


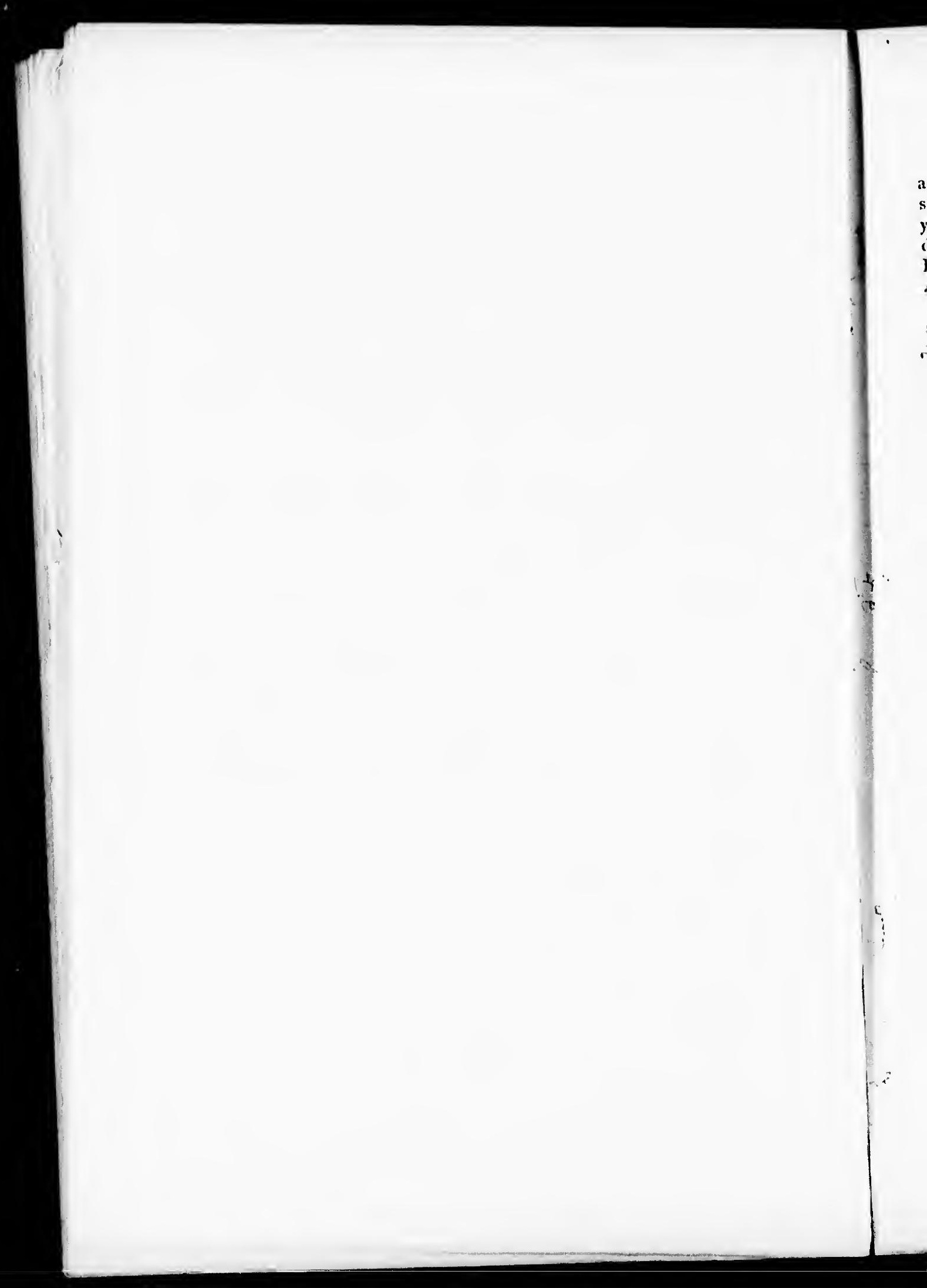


anxious to awail themselves of it, hit were fortmately not permitted to do so. Afterwards I happened to sec: Mr. I'enatell, and I asked him : - "Did you people at the Colonial Office put up loord Salisbury to say what he did the other day in the House of I.ords?" "Oh dear, no," saiti Mr. Penucll, "those are Mr. Waldington's views-Mr. Wadlington, the lirench Ambissiddor"! I think no furlher comment is needed.

I will just saly a word as to the intringement by liance of the treaty

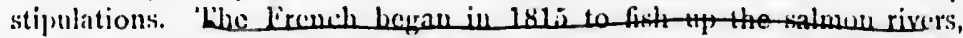
, poiched on the Labrador coast, Hinfered in cortive places, erected buildings of a more substamlial character then allowed by the treaties, exported lumber to St. Pierre and Miguclon, barred the rivers with fishing weirs,

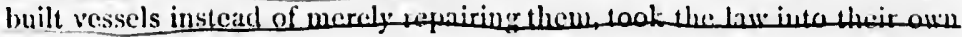
hands, and left their boats and other gear on the coasts, which they hanl no righlit to do by treaty.

These infringements of the treaty are clibefly to be found in a report by Mr. J'erley, who was a Now.Scotian, cmployed by the Foreign Onice. IIe was sent ont to Newfoundland in 18:i 7 to enquire into the alleged grievances of the lirench, who complained that our settlers had interrupted them in their fishery rights. Mr. Perley used to tell the following story. He was over here before sailing for Newfoumdland, and went to the lioreign (office one day, when one of the P'ermanent secretaries said to him :-.. When you are about it, Mr. Perley, you might as well make a report on the fishing difliculty which hats turned up at Vanconver." Mr. Perley said :-.. "Certainly I can do that after I have finished with Newfoundiand, but it will take me some time to get there" (he would have to have gone romd by Cape Ilorn in those (lays). "Ilyy," satid the gentleman at the Furign Uffice, "the two places are close together, are they not?" I hope the geographical knowledge of the Foreign (Aflice has improved since that date. With regard to the lslands of St. I'ierre amel Miquelon, the lench have a right to fortify them, because the proviso made in the: treaty of 1673 which prevented them loing so was not repeatid in the: sext treaty ; but they can only fortify them to the extent that they must not berome an object of jenlousy. That is rather indcinite, hut that is the opinion of the law officers of the Crown.

With respect to Mr. Perley's reprort, the law officers remarked:"We do not discover in these palpers that any just caluse of complaint against the British fishermen or settlers exists. The only gricuantes scem to be those sustiined by them."

As regirds St. Pierre not being an object of jealousy, it is cortainly so, as it is a nest of smugglers. We are not cren allowed to hawe an agent there; while at St. John's there: is a French agent, a .I. des Isles, who performs all the duties of a consul, is, in fact, a spy, who is at the bottom of a good deal of the friction beliwen the two nations.

Our Covernment up to that time did not alpear to have tisken much notice of these illegal actions by the firench. () this heal the law officers of the Crown male some very pertinent remarks, ruferring to the (ircy Islands and Belle Isle: North, where the lirench had attempted to cxercise exclusive rights. The law oflecers say these islauds, being in the

Pinteignt Mllive nlalur. Istiti. 


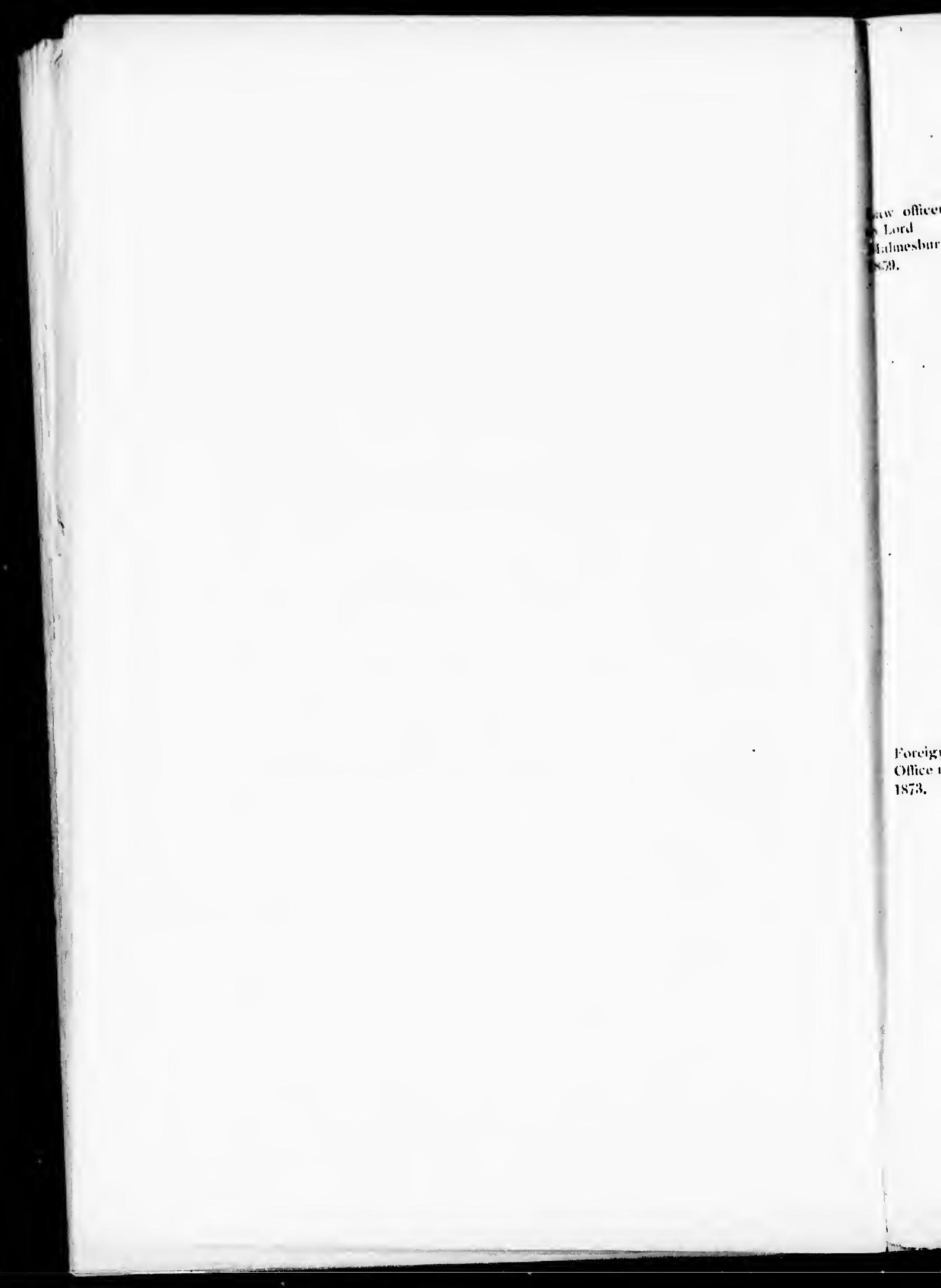


Atlantic, and not in the (iulf of Sit. lonwrenec, where islinds on the const are alone mentioned in the flcatics, the firench have no right there; and they ge on to sily this. "This apprears to us to be only one of thr mume rutes instances in which the firench by encroaclunent, and profiting by the supurness or tacit ac puiescence of (jeat liritain, are steadily proceceling.

1. To convert easements or rights of uses in property.

2. I'o cxtend concurrent rights into exelusive rights, and

3. To interrupt and destroy lititisls exclusive rights in a wanton manmer."

They further sity :- "Wre renture to point out that the encroach. ments and violations of stipulations appear to be entirely linench; we: would therefore sugrest the importance, first, of vigorously asserting all liritisle e.visting rights, and being prepared to maintain them for the future, in casc of need, ag:ainst their cutire destruction or total interruption by France. IVe do not observe that this has ever been tone on the coist of Newfounclland." The same thing might have been said yesterclay, or at all events up to the time of the present fovernment coming into power, up to which datc, at any rate, the excellent advice hats, been more or less ignorel.

Now as to the general grievances of the prople of the istands residing on or frequenting the areaty shore. 'Thicy have been driven out of harbour by french men-of-war when not fishing at all, or when fishing where no lirenclunen were near, in which citse there: could ise no interriytion. They have had their nets and fishing gear clestroyed by French naval ollicers even when not molesting litench lishermen. In any case. the French have no right to take the law into their own hands. A very gross calse is referred to in the lineign ()fice memoramlum of 1873 , when

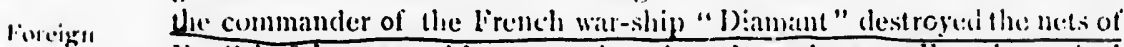
Onice meno. Jinglish fishernen without warnine, in a hay where ne tirenchmen had 1873. Nrejuented for thirty years, and where none were present. This wat considered a direct assertion of the leneh claim of cxclusive right to lish. ()ur (iovernmicut protested, and the only answer lond (irinville received was that these acts of the firench naval oflieers were defendecl.

No Newfonndlander has ever, as far as I can iscertain, recrived any compensation for such illegal destruction of his property. "To a poor fisherman the destruction of his nets is not a mere "pin-prick," hut a stal) in his vitals. Of late $y$ ears it is not the dirols fishermen arainst whon there are complaints, hut the: French naval ollicers. Commimder Kuowles stated in his report abont 1873 that the French and Jinglish fishermen got on well enough, lut when a French man-ofwar appeared it interfored with our people.

For many years the treaty shore was a sort of no man's lind, and the resiclents were not represented in their House of Assembly.

The British Gusermment relused to allow Newfoundilanders to have grants of land on that part of the coast, and also refused to allow the Government to appoint magistrates there. In 1873 the Colony mate a very strong appeal to allow the apyointment of magistrites on the treaty shore. 'There were then a good many people scttled there-some $(j, 000$. 


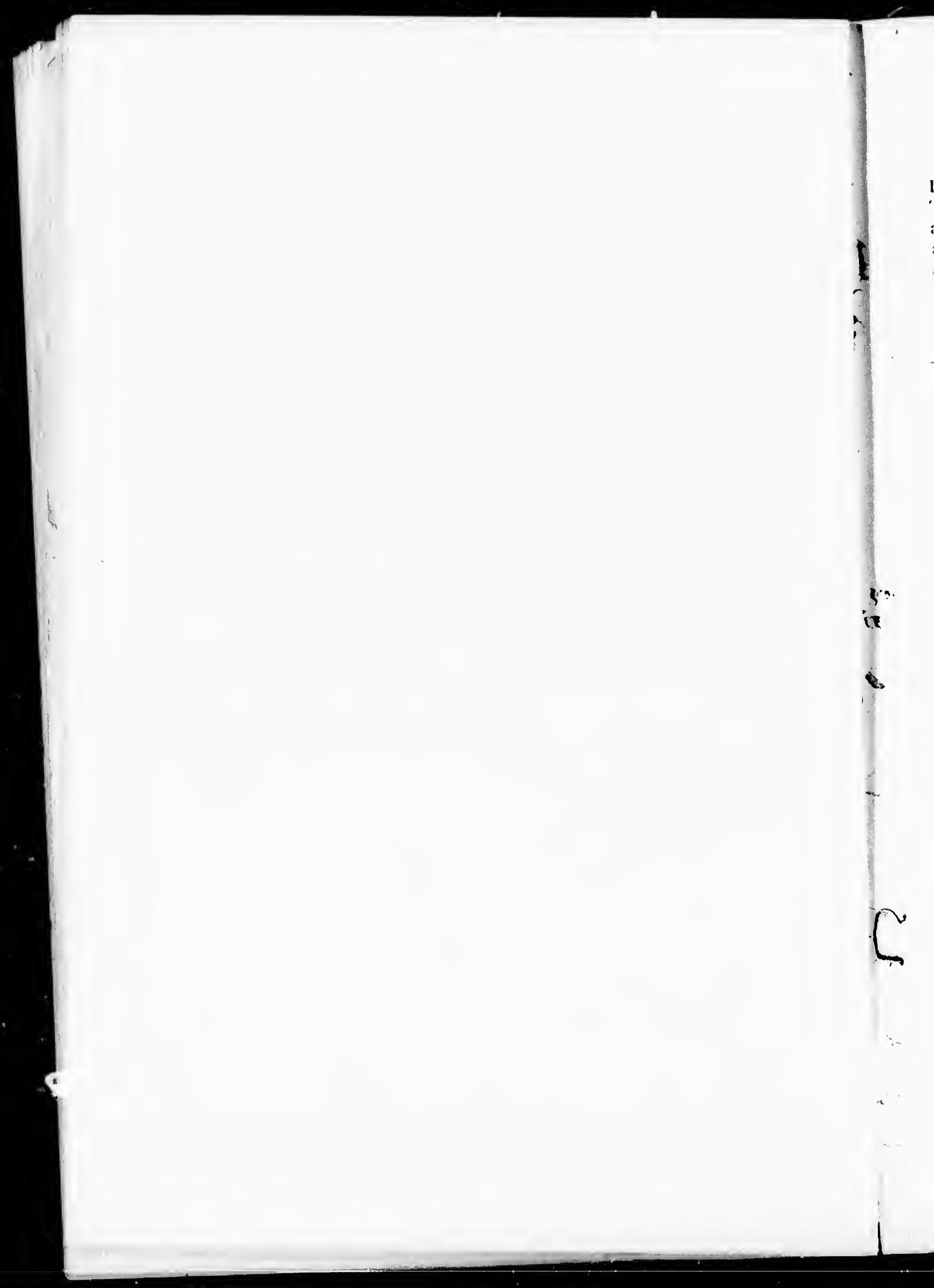


lore Ciranville, who was then in office, asked the firench if they ohjected. 'They did not answer for six montls, and then they saitl they woukd not

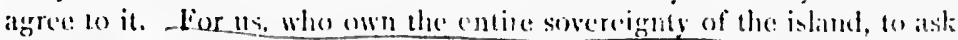
Prercignt ()tilin mertur. a forcigni l'ower for libertg to carre an juriseliction in outr owill territory, and appoint magistralles there, was nol only quile monocessary. but a very ignominious procecdingr. Lord Granville: alfermands actually astied the

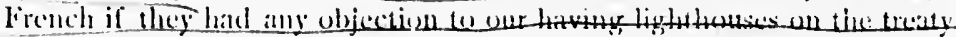
shore. He linench on this occasion were pleased to sar thes had in objection. Jagistrates wore not ilp pointerl until $18 \mathrm{~s}$.

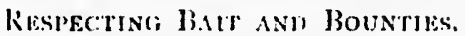

Perhaps now I hat better herin ly telling you whan bait is. The bait early in january is herrings; then come caledin, a very small fish about as big as a smelt, which comes in rountless millions to the shore. Then later on come squids, which is a small cuttle-fish. Farly in the eighties the firench increased their bomties considerably. Formerily the Frecich only gave bonnties to vesicls fitted ont in France. Iater on they gave bounties to vessels fitted out in St. Pierre; this hal the effect of increising their chteh, so they invited neutral marliets. Formerly most of their lish was consumed in liance. The bounty wats sometimes 50 to

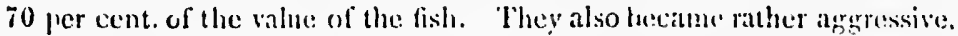
and the Sewfoumdlankers in retaliation determined that they would not allow the French to buy bait on the non-treatt shores so they bronght in

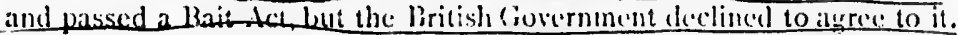
They bronght it in angitil the following year, in 1s87, but the 13ritish

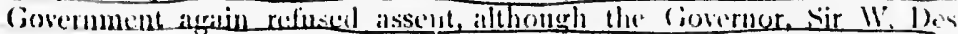
Fous, hasked up the Colony in a very powerful despateh. Jerd knutsford gave ats the reason that the French objected to it! Very likely, ats it was brought in esperially to hamper them. In the same gear, 18si, all the Colonial P'remiers came over here, and all the other Colonial l'remiens

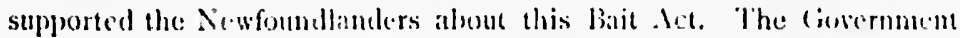
gave way, and the Rougal assent wats at length given to the det, which at few months before wats refused. This latit Aet wathenglit into force the next year.

Now the herritg are found in these twe salys, viz., lientume and Placentia, which ate only about fo miles from the anks, in January, three or four weeks carlier than on the tecity shore at st. (icorge's, which is round (ape kay, which is some 200 miles from thr banks, where any' onc can ?islı. If in these first three or four wecks the linench cannot get hat in Fortune and Placentia Bays, then they cames gol fresh herrings at a!l. It is certainly true that the French have caltght al species of shell-tish wel

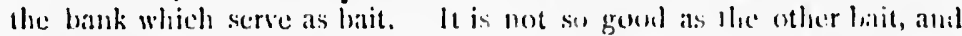

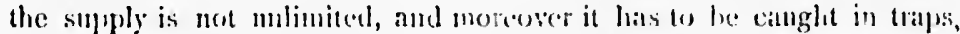
which ailses time and tronble, finm rm the French on the banks got all

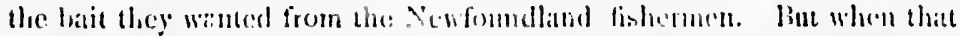
supply wat (att off they had to gro round Cape kay to the traty shore to eitch bait, noarly iwo hundred miles away, sometimes more; this entailed anucl: loss of time. 'A great olject is to have the bait fresh, and if the lirenchman lits to go so far lie commot get it freshih. 


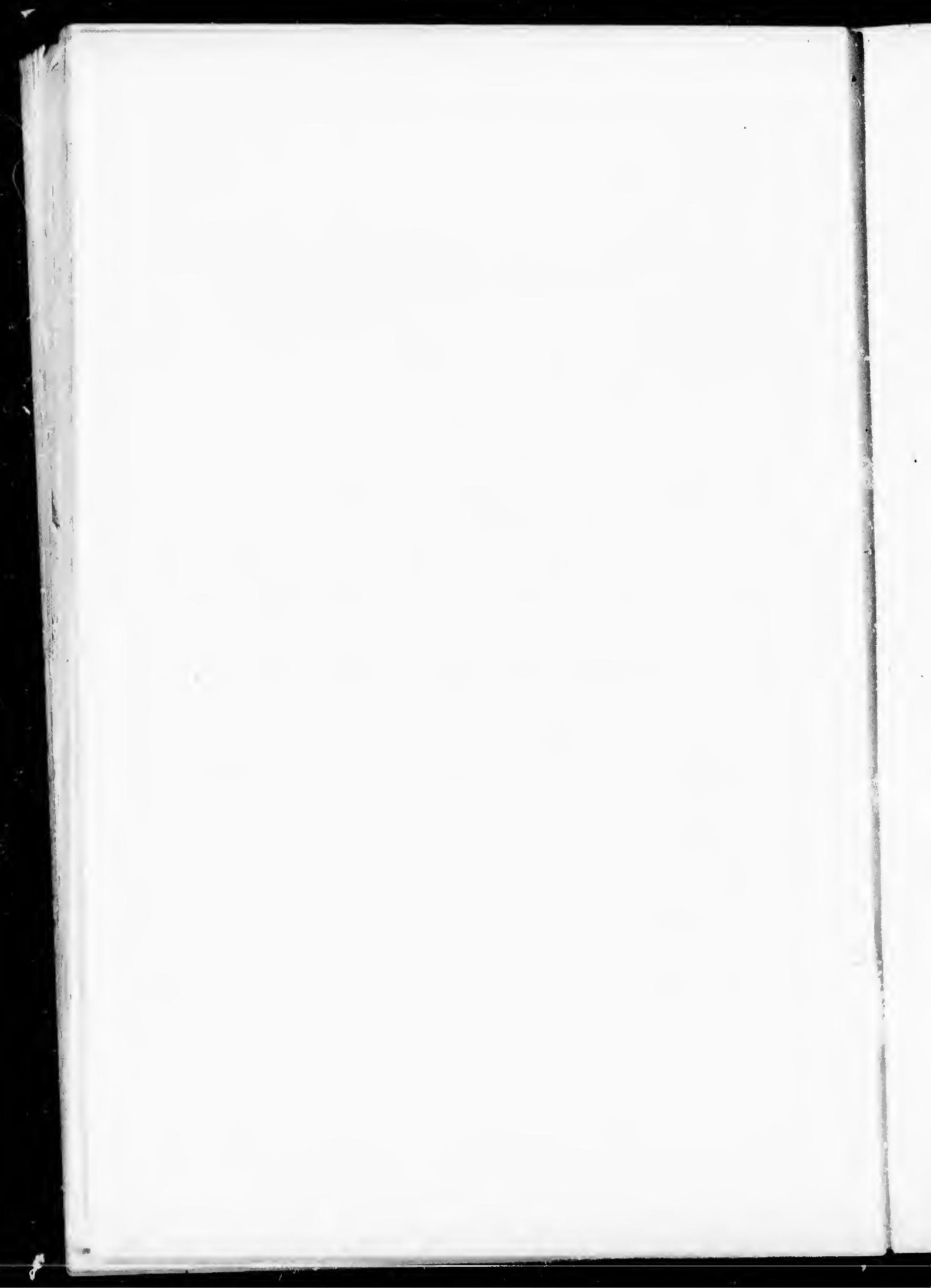




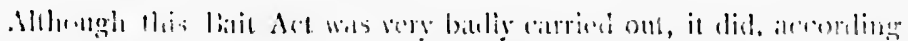

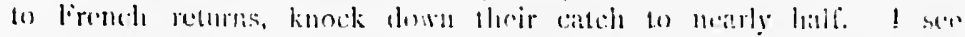

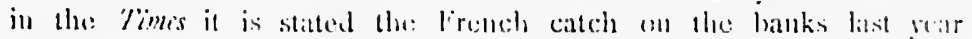

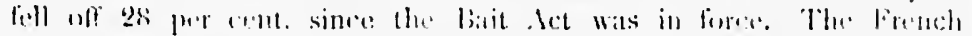

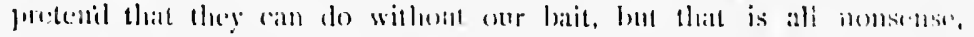

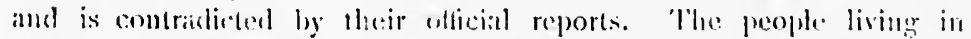

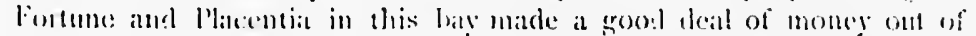

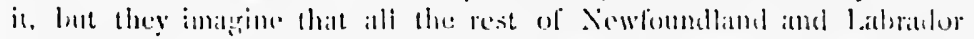

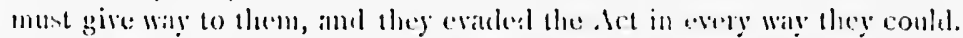

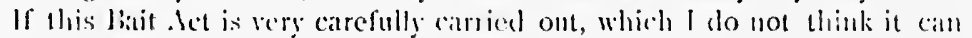
he willumt the assistinte of lingland, it will be a very grood thing. If they hate a doren or lilteen ste:an launches mammed by time-espired blate-

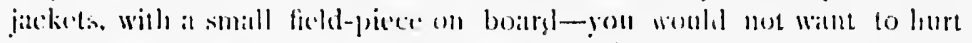
anyone, but only to put at shot through the mainsail ef the first schoremer

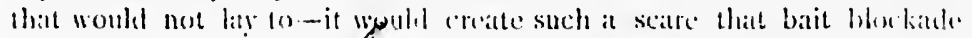
moning would soon ceatse. (There is no doubt but that the prevention of

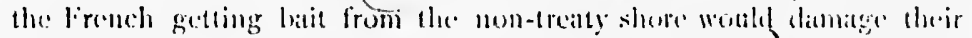

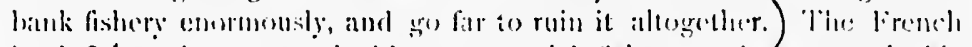
bank fishery is a very valuable commercial fishery, and a very baluatile:

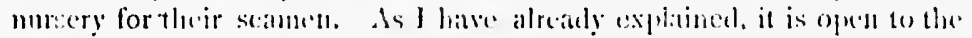
worle. There are jolenty of dmericans and camalians there. It is

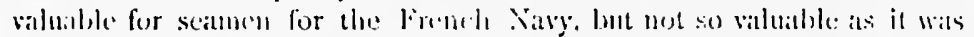

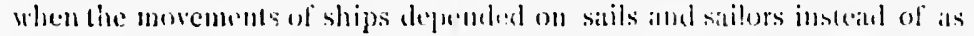
now on steam and stokers. (commereially it is rery viluable, and llete

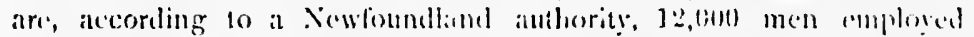
on these beanks and some: blot vessets. In the tronty shore the liahery is

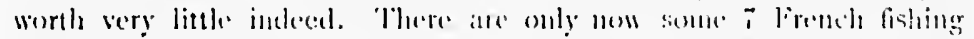
stacons. empioning some 250 men, where formerly there were more than

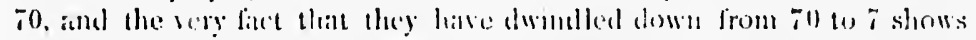

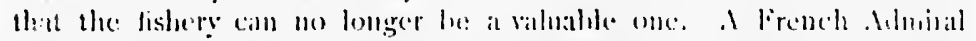

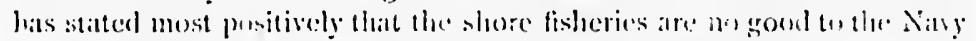

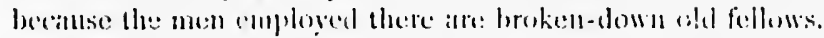

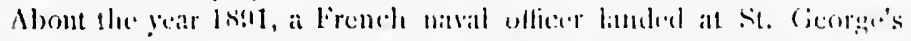

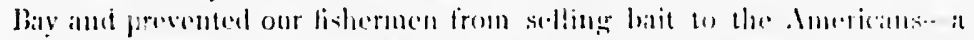
most outrigeons action, which the firench liewermenent crentually disowned and apologised for. Sulsedpenty, regrolations sere mate

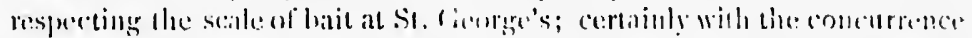
if not all the instigation of the home anthorities, hy which the fiench

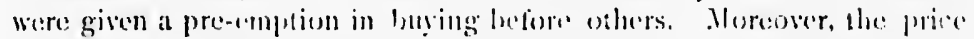

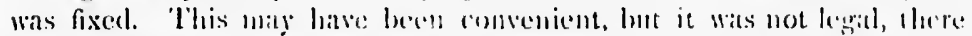
was nothing of "the open door" about it, for white the toor wat held

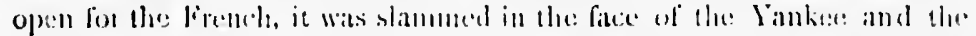

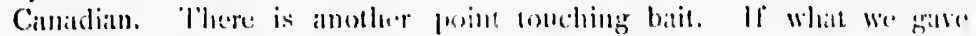

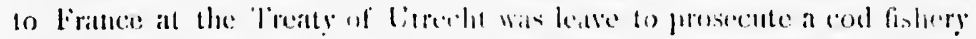

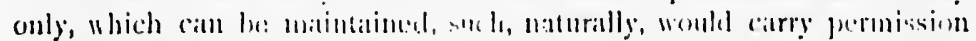

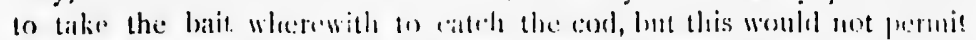

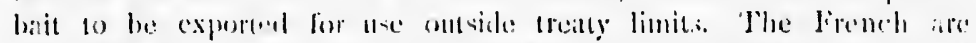
fermitted to cut wood to butild stiges on ile treaty shore, but not to 


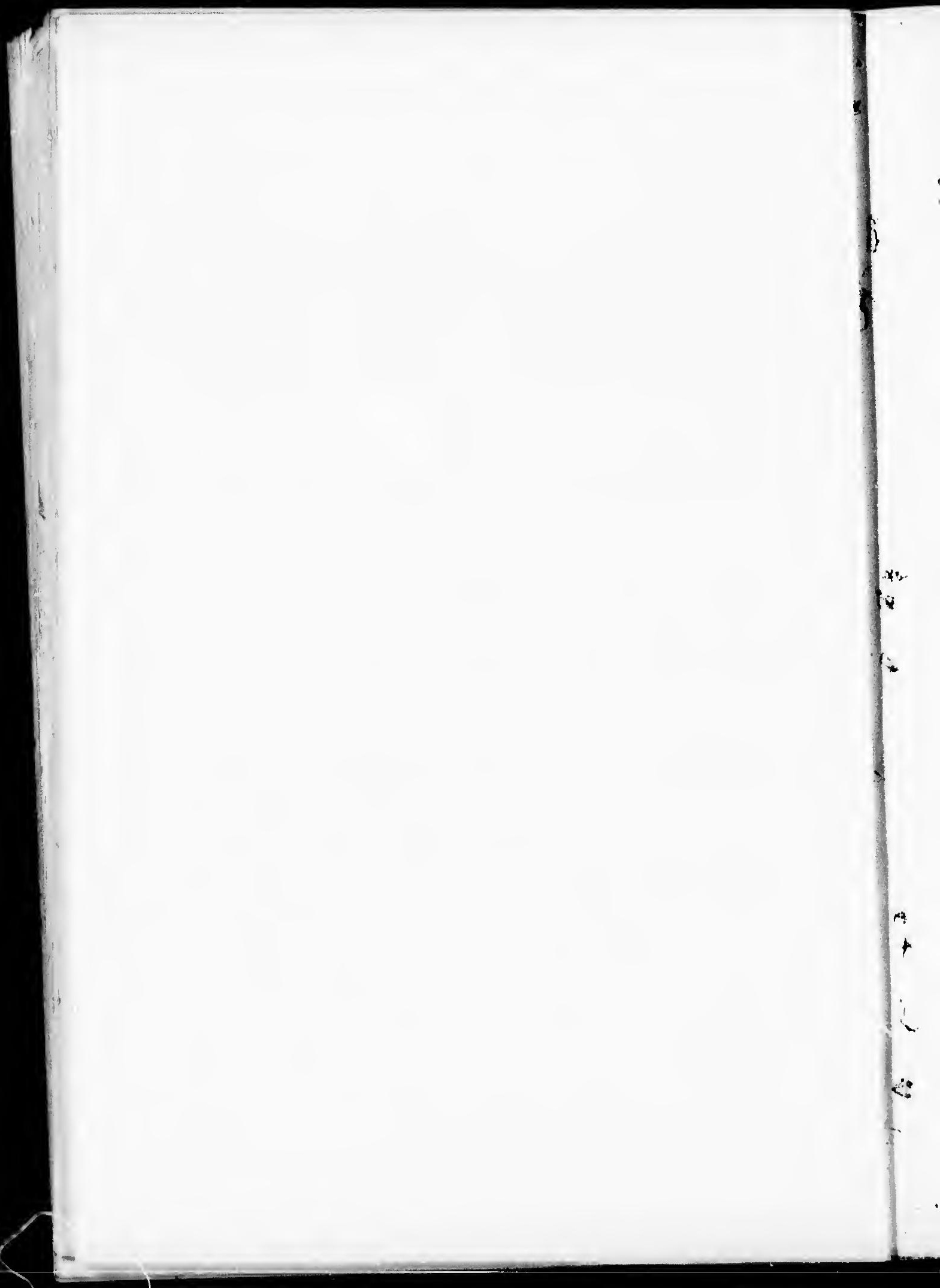




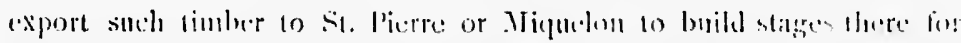

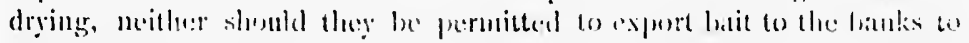

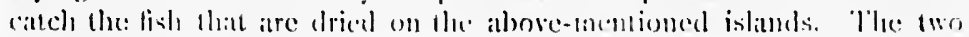
things atc on all fiurs.

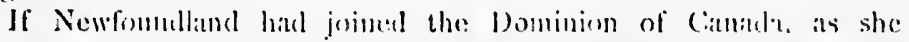
should have dome, she would have hat at stronger hamel of this the

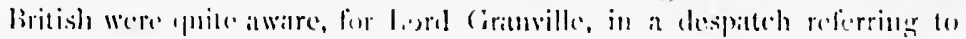

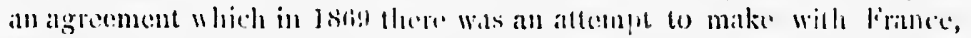

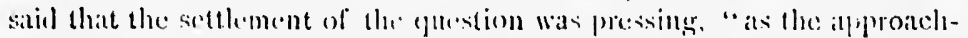
ing union of Xewfoundland to Cimblat might render the guestion less trastable by increasing the mumber and importance: of those interested in

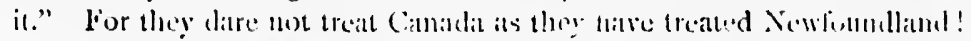

These lidlias and gentlemen, as fatr as i hase been ible to axplain in the time at my disposal, ane the main points in this fishery guestion of

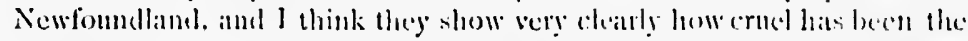

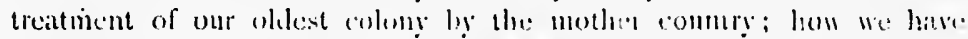
pielded to the exargerated pretentins of leance; how the rights of Newfoundland have been sileriliced in a wimton manner: and how an

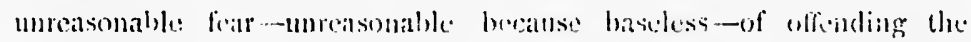
susceptibilitites of the firench hats so tregurntly dominitud Downing Strect.

I have only one more word lo saly. There has leen a Royal Commission. Ile have no reation to have much fith in them, ats they are

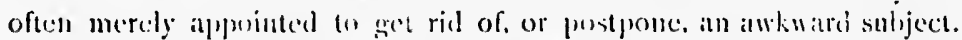

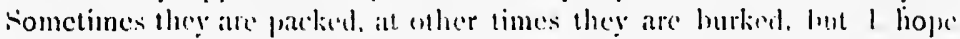

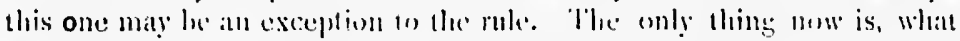

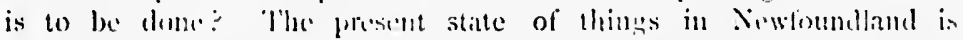

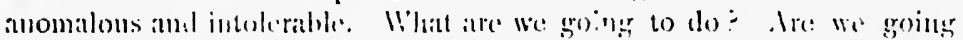
to abrogatc tlu. treaty : I think mot. Rusial might hate tone so. Are:

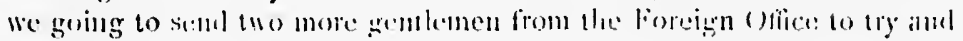

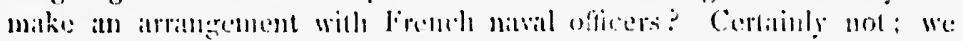

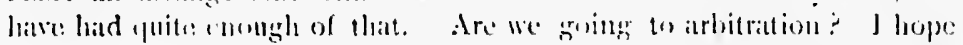
not, for we are sure to he dune! Are we to buy them ont: Xol aliogether. Me may hase to prite something. I remeember at the time of

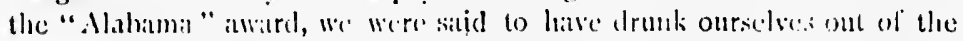
"Nabatma" ditlienity. I (1) mot know what the drink bill will les this yeats.

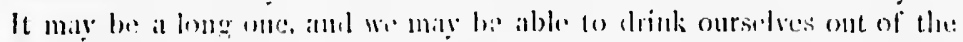

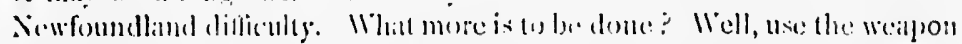

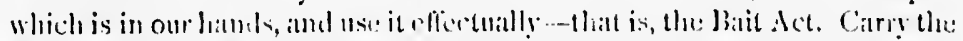
Batit . let out to its lltmost limit, an! you will more or less ruin the livenel bank fishery, which, as I hatwe almaty said, is very valuable, whereats the shore fishing is worth very little: inteced.

As the propte of all clisses and pulitical opinions hate come to the conclusion that they are tirud of heing fit upun by linance in various frats of the carth, and, what is more, are not going to stand it any. longer, we maty lepe that this malter will before long be brought to it sitisfictory comelusion-at conclusion that will sattisly mot unly framece. lut Newfoumllam! 


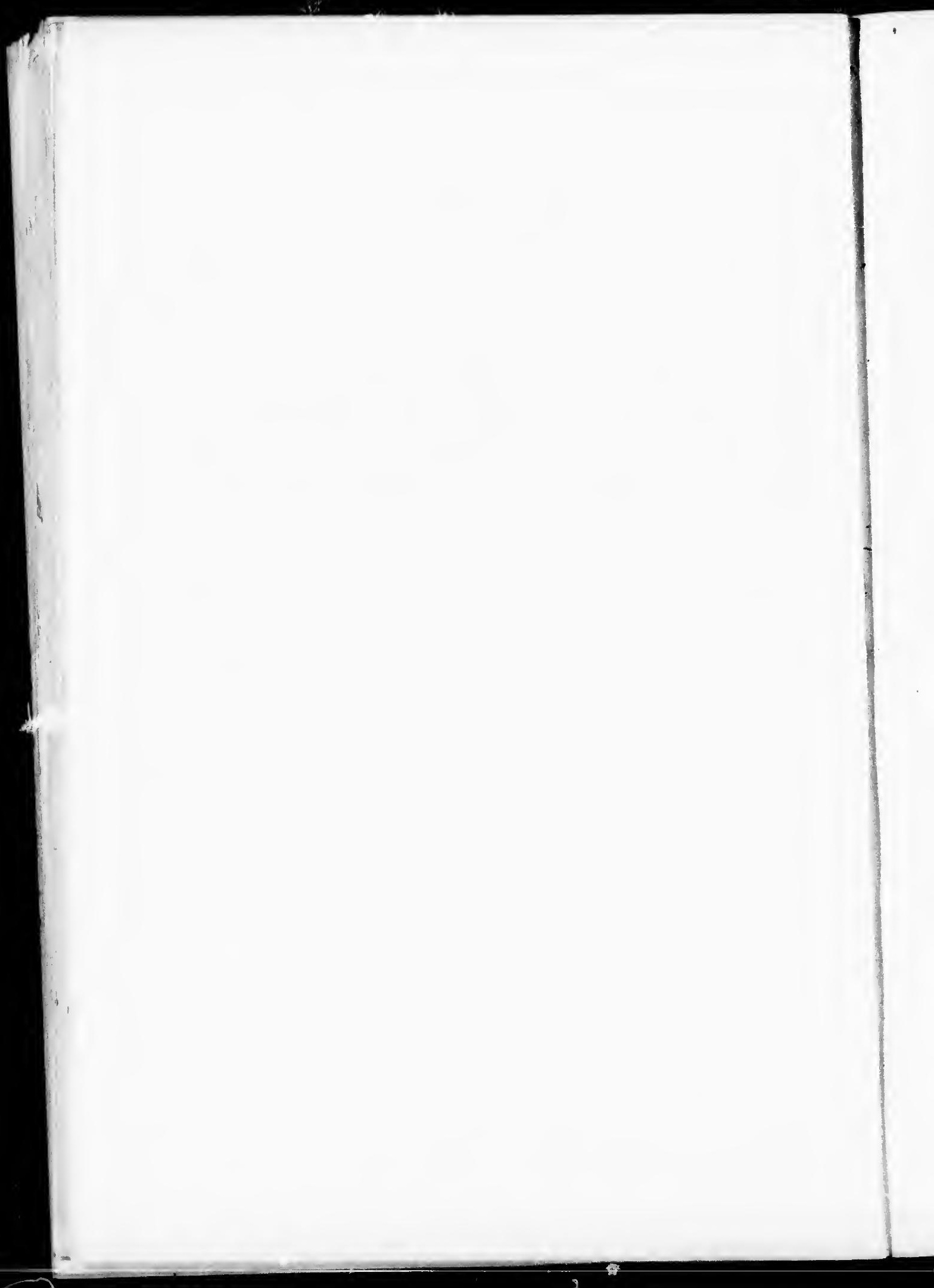




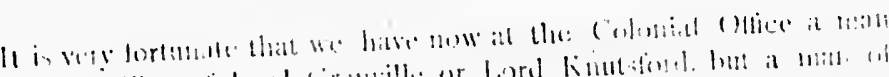

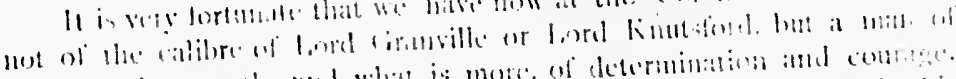

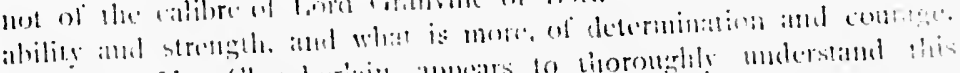

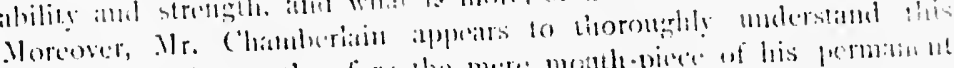

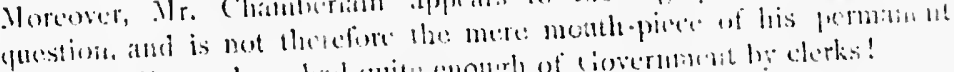

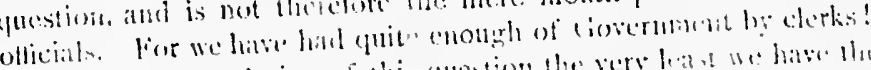

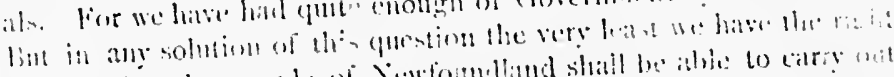

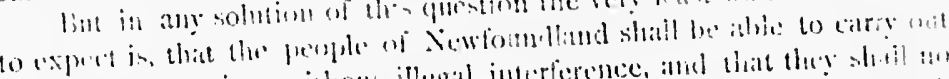

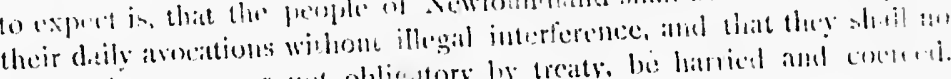

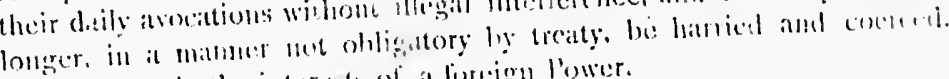

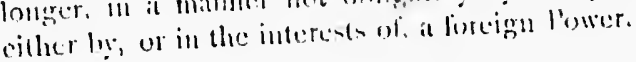




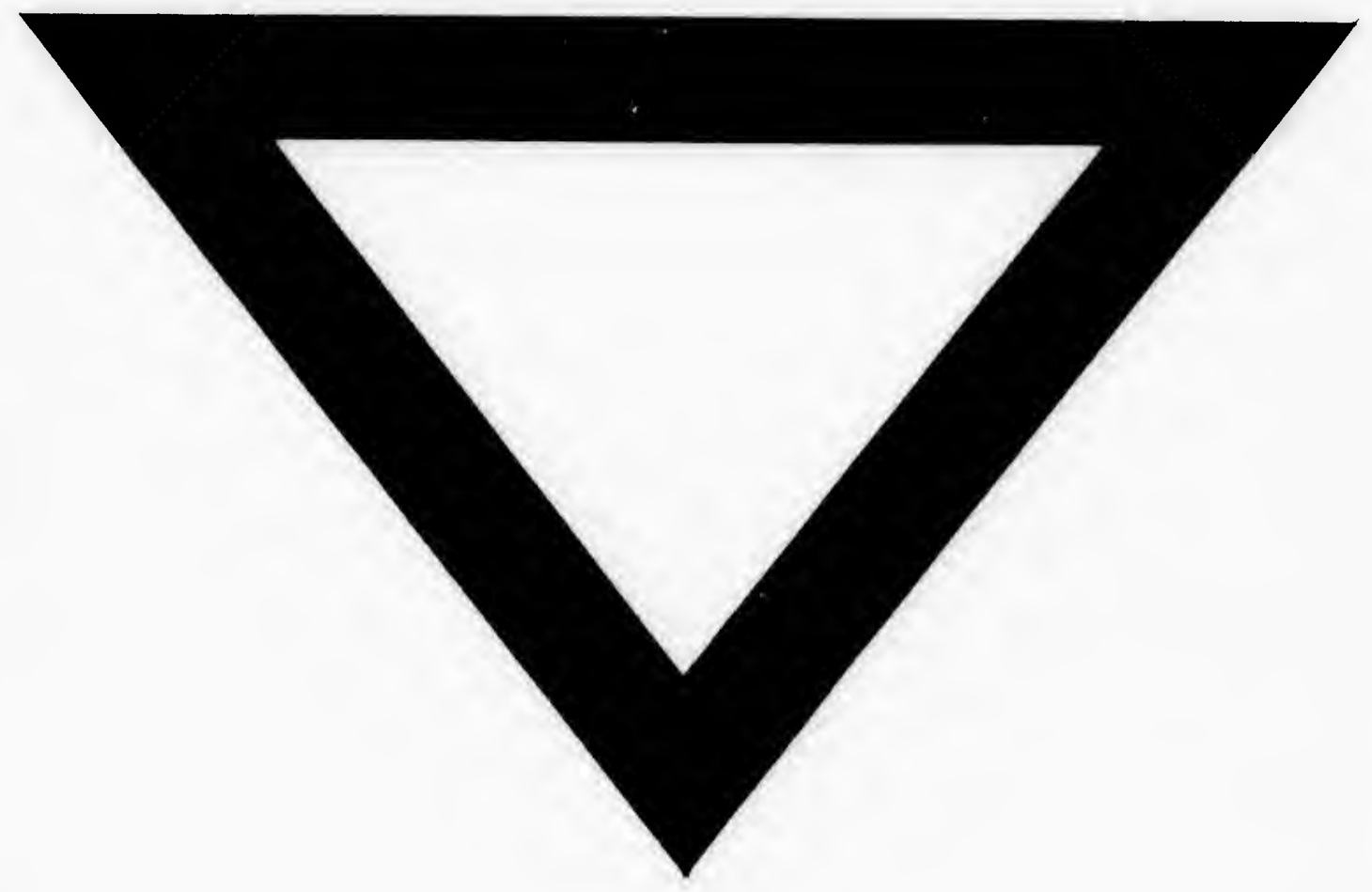

